\title{
Leaders and Followers in a Hot IPO Market
}

\author{
Shantanu Banerjee* İsmail Ufuk Güçbilmez ${ }^{* \dagger} \quad$ Grzegorz Pawlina*
}

December 21, 2009

\begin{abstract}
We explain why some private firms lead a hot IPO market by going public early, while others follow by delaying their IPOs until late in the same market. In our model, there is uncertainty about the future state of economy and going public is valuable only in the good state of economy. Consequently, firms have to decide whether to go public now or to wait until the state of economy becomes known. Bad firms always wait. If the economy turns out to be good (bad), they go public (remain private) and incur (save) issuing costs. Good firms, which can increase their probability of success by pre-committing to invest, may prefer to go public immediately. They, however, have to underprice their shares, since bad firms have an incentive to mimic them otherwise. We find evidence for our arguments in the U.S. IPO market: Early IPOs of a hot market are underpriced more severely on average, but they experience higher growth in sales, assets, EBITDA, and capital expenditure. Moreover, their shares outperform the market up to nine months after their issues, while those of late IPOs underperform the market from the start. JEL classification: G32; L1

Keywords: Initial public offerings; underpricing; first-mover advantage
\end{abstract}

\footnotetext{
*Department of Accounting and Finance, Lancaster University, Lancaster, LA1 4YX, UK.

${ }^{\dagger}$ Corresponding author. Tel: +44 (0)1524 592445 Email: i.gucbilmez@lancaster.ac.uk.
} 


\section{Introduction}

Monthly volume and underpricing of initial public offerings (IPO) co-vary substantially over time. This co-variation creates IPO waves. The literature refers to the peaks and the troughs of IPO waves as "hot" and "cold" IPO markets respectively. Hot markets are characterized by higher-than-usual volume and severe underpricing. Cold markets, on the other hand, feature dormant volume and mild underpricing.

IPO waves have been analyzed extensively in the literature. There is still no consensus view of the hot market phenomenon, however. According to one view, hot markets emerge when the cost of capital is temporarily low (due, possibly, to investor irrationality), because firms seize the opportunity to issue overvalued shares. Another view suggests that fluctuations in IPO volume and underpricing stem from the time-variation in conditions of (a rational) market.

We review the literature on hot markets in Section 2. We find that although much attention has been devoted to the differences of IPOs between hot and cold markets, little is mentioned about the differences of IPOs within a hot market. These differences matter, however, since most of the IPOs in an economy, by definition, take place in hot markets. Moreover, they exist, since hot markets usually last long enough to distinguish between "leaders" and "followers", which are firms that go public early and late in a hot market respectively.

The purpose of our paper is therefore to explain why some private firms of a cohort lead a hot market by moving first, while rest of the cohort follows by moving later in the same hot market. We develop a two period model. In the first period, there are no growth opportunities and the future state of economy is unknown. In the second period, the state 
of economy is revealed. If it is good, private firms can invest in a project, which is either low- or high-growth, by going public. In this setting, we assume that some firms have an intrinsic first-mover advantage, which is equivalent to a higher probability of investing in the high-growth project. There is a cost and a risk of being a leader, however. The cost is the underpricing of shares. Leaders lose their advantage if they cannot preempt other firms. These other firms have incentives to pool, if investors, who cannot observe the type of firms, value them as leaders. Therefore, leaders content with issuing underpriced shares to separate themselves from the rest of cohort and to maintain their advantage. The risk is that, if the economy turns out to be poor, the projects would not add value, and the leaders make a loss due to the issuing costs they incurred in the first period.

Our model shows that firms which possess the first-mover advantage lead a hot market if the shift in their probability of investing in the high-growth project is higher than a critical value which depends on (1) the probability that the economy will be in a good state, (2) the issuing costs, and (3) the value differential between the high- and the low-growth projects. It also predicts that the shares of leaders are underpriced, while those of followers are fairly priced. We construct testable hypotheses based on our model's outcomes: First, early IPOs of a hot market should have more valuable investment opportunities and suffer from a higher degree of underpricing. Second, early IPOs of a hot market can be distinguished from late IPOs of that market, not by their pre-IPO characteristics, but by their post-IPO growth and performance.

We test our hypotheses using a sample of U.S. firms that went public between 1970 and 2008. We identify 9 hot markets within our sample period. Our hot market definition performs better in terms of its robustness to the sample period length than the existing 
definitions. We find that IPOs which take place in the first half of a hot market are underpriced more severely on average, but firms that conduct those IPOs (i.e. leaders) have higher market-to-book ratios following their IPOs. Moreover, although pre-IPO characteristics cannot predict whether a firm is a leader or a follower in a hot market, being a leader has explanatory power on post-IPO growth. In particular, firms that go public in the first half of a hot market experience higher sales, assets, EBITDA, and capital expenditure growth expost, even though they have similar ex-ante characteristics with firms that conduct an IPO in the second half of that hot market. Finally, although the shares of late IPOs underperform the market from the start, those of early IPOs outperform it up to 9 nine months.

The rest of our paper is organized as follows. We, first, review the literature on hot markets (Section 2). Then, we model going public and IPO timing decisions of private firms, and develop testable hypotheses (Section 3). Finally, we empirically test our hypotheses using a sample of U.S. IPOs and our new definition of hot markets (Section 4). We conclude with a discussion of our results (Section 5).

\section{The Literature on Hot IPO Markets}

There are both theoretical and empirical studies in the literature on the cyclical nature of IPO activity in terms of volume and underpricing. These studies put forward various arguments for the emergence of hot markets. We present these arguments under four groups: (1) Market Timing, Investor Sentiment, and Issuer Objectives, (2) Business Cycle and Adverse Selection, (3) Risk Aversion and Private Benefits of Control, (4) Sequential Learning and Costly Information Production. 


\section{Market Timing, Investor Sentiment, and Issuer Objectives:}

Alti (2006) argues that valuing the shares of private firms is more difficult than valuing those of public firms, due to higher uncertainty and asymmetric information that surrounds the former type of firms. Consequently, managers can benefit significantly if they issue shares during hot markets when the cost of capital is temporarily low. That is, they can time the market and raise more proceeds than they actually need. He finds that firms raise substantially higher proceeds during hot markets, after controlling for firm characteristics. Pagano, Panetta, and Zingales (1998) provides further evidence of market timing. They find that IPOs become more likely when industry market-to-book ratios soar, while investment and profitability drops after the IPOs.

The findings of Ritter (1991) support windows of opportunity and investor over-optimism, in that he finds firms that go public during hot months underperform the worst among all IPOs. Schultz (2003) defends that abnormally poor performance of these firms is an artefact of event-time methodology, and such performance would vanish if calendar-time methodology is used. The idea is that, with event-time methodology the probability that hot market IPOs will underperform is high, even though ex-ante expected abnormal returns are zero. As a result, hot markets IPOs appear to underperform, and create an impression that managers time the market and issue overvalued equity.

Helwege and Liang (2004) compare firms that go public in cold and hot markets. They find that hot markets, overall, are not dominated by firms from particular industries, and the qualitative differences between firms that go public during cold and hot markets are not significant. Moreover, they do not find cross-sectional differences in the operating performance of firms during the years that follow the IPOs, hence dismiss the market timing argument. 
Instead, they endorse the view that hot markets are mainly driven by investor optimism, but they do not take a side in terms of the rationality of such optimism.

Loughran and Ritter (2002) make use of prospect theory to explain time-variation in underpricing. They argue that issuers contend with underpricing when the offer price is adjusted partially upwards as a result of positive public information revealed during the registration period. They, then, present an equilibrium theory of hot markets, such that positive market returns lead many IPOs that have overlapping registration periods to be underpriced, hence creating a wave of severely underpriced IPOs. Ljungqvist and Wilhelm (2003), on the other hand, claim that severe underpricing during the Internet bubble period, a very hot market, was due to lower level of insider ownership and smaller number of secondary shares sold. Loughran and Ritter (2004), however, do not find any relationship between secondary shares and underpricing, and show that although CEO ownership was lower in percentage terms during the bubble period, it was in fact higher in dollar terms. They instead argue that there has been change in issuer objectives, such that issuers no longer care solely about maximizing IPO proceeds, but also are after star analyst coverage and hot IPO allocation, services supplied by investment banks that have a track of underpriced IPOs.

\section{Business Cycle and Adverse Selection:}

Pastor and Veronesi (2005) present a rational model of optimal IPO timing. In their model, private firms find it valuable to wait for going public until the market conditions improve sufficiently. When the improvements arrive, many private firms, those that have been waiting, go public around the same time and create a wave of IPOs. The authors hypothesize that improvements should benefit public firms as well as private firms, hence IPO waves must follow high market returns. They test this hypothesis empirically, and find 
that IPO volume is indeed higher following stock market run-ups.

Yung, Colak, and Wang (2008) complement time-varying market conditions with timevarying adverse selection costs. They argue that when investment opportunities are better, firms can sell securities at higher prices, and this tempts poor firms that are indistinguishable from good firms in terms of observable characteristics to pool. As a result, when market conditions are good, a higher number of poor firms go public alongside good ones, hence uninformed investors underprice the lot more severely. This explains why high volume goes hand in hand with high underpricing. The authors find evidence that the variance of long-run returns is higher for firms which go public during hot markets. They interpret this as a result of the revelation of poor firms' unobservable characteristics over time.

Lowry (2003) empirically tests business cycle, adverse selection, and investor sentiment arguments in terms of their ability to explain IPO cycles. She finds that business cycle and investor sentiment can explain time-series variations in IPO volume well, but adverse selection have no economically significant explanatory power. Note that, she assumes adverse selection costs are counter-cyclical as in Bayless and Chaplinsky (1996), who study SEO cycles, and not pro-cyclical as in Yung, Colak, and Wang (2008).

\section{Risk Aversion and Private Benefits of Control:}

Zingales (1995) focuses on the control aspect of going public. In his view, if the owners of a private firm eventually aim to exit, they might find it optimal selling part of their ownership to atomic investors by taking their firm public first. They, then, sell their remaining part of ownership to large investors by a block transfer. This happens if the market for voting rights is not fully competitive, while the market for cash-flow rights is perfectly competitive. The owners extract the full value of the cash-flow rights from atomic investors, and reduce the 
value over which they bargain with large investors. According to this view, going public with the eventual aim of exit makes more sense when cash-flow rights are relatively more valuable than voting rights. Moreover, the value of security benefits that derive from cash-flow rights is more sensitive to aggregate fluctuations in the stock market, while the value of private benefits that derive from voting right is less sensitive to them. The author offers this as an explanation for the existence of IPO waves, such that high IPO activity follows an increase in stock prices.

Benninga, Helmantel, and Sarig (2005) model IPO timing as a trade-off such that a risk-averse entrepreneur loses his private benefits after going public, but benefits from diversification. They find that it is optimal for a firm to go public, and give up private benefits, when its cash-flows hits a certain threshold. Consequently, they argue that IPO waves occur and coincide with high levels of market because positive shocks to economy increases cashflows of many firms. This argument matches that of Pastor and Veronesi (2005). The model of Benninga, Helmantel, and Sarig (2005) is, however, at odds with that of Zingales (1995), since in the former model the entrepreneur cannot enjoy any private benefits after taking his firm public, and if these benefits become relatively more valuable he takes the firm back private.

\section{Sequential Learning and Costly Information Production:}

Lowry and Schwert (2002) analyze the relationship between IPO underpricing and volume. They find that more firms go public following periods of severe underpricing. They claim hot markets emerge when positive information is revealed during registration periods of IPOs. This positive information is partially incorporated into the offer price, hence severe underpricing. It induces more private firms to go public, hence high volume following severe 
underpricing.

In the model of Hoffmann-Burchardi (2001), hot markets emerge when industry prospects become more uncertain, such that risk-averse entrepreneurs become more inclined to exchange their firms with risky cash-flows with safe proceeds from IPOs; and when investors free-ride on the information produced in the prior IPOs, so that entrepreneurs do not compensate them for their information production costs.

Benveniste, Busaba, and Wilhelm (2002) argue that if pioneer IPOs bore the entire cost of information production, while following IPOs free-rode, IPO market could break down. Thus, they explain clustering of IPOs by the efforts of investment banks to bundle them, so that they distribute the information production costs across IPOs in the form of underpricing. Benveniste, Ljungqvist, Wilhelm, and Yu (2003) provides evidence for this argument. They find that although IPO volume and underpricing are positively correlated in aggregate, underpricing falls as the size of bundle increases, since each IPO in the bundle bears a smaller fraction of the information production cost.

\section{Model}

We consider an economy with a cohort of private firms. This economy has a good and a poor state. The probability of having the good state is $q$, where $0<q<1$. In the good state, firms have access either to a low- or high-growth project. The low- and high-growth projects add the values of $V$ and $(1+f) V$ respectively, where $f>0$. In the poor state, these projects do not add value. The probability that a firm will have access to the high-growth project is $0 \leq p \leq 1$. Both of the projects need capital investment $E$. Private firms raise this capital by 
issuing common stock. ${ }^{1}$ After their issues, owners of private firms retain $\alpha$ fraction of their companies, and investors get the remaining fraction in return for their equity investment. All private firms have assets-in-place worth $A$ prior to their issues. The costs of going public amount to $c$, where $0<c<V$. Owners and investors are risk-neutral, they do not have time preferences, and investors compete among themselves for investments.

In our economy, there are two time periods: $t \in\{0,1\}$, in which owners decide whether or not to conduct an IPO. At $t=0$, the future state of economy is unknown. At the start of this period, firms learn weather they are "leaders" or "followers". Leaders enjoy a firstmover advantage, such that if they go public now and if followers wait, they increase their probability of having access to the high-growth project by $\Delta$, where $0<\Delta \leq 1-p$. If they wait or if followers also go public now, this advantage vanishes. Investors cannot observe whether a firm is a leader or a follower.

\subsection{The Going Public and the IPO Timing Decisions}

At $t=0$, firms decide whether to go public or to wait by comparing the expected net payoffs of these two alternatives. If they decide to wait, they choose between going public or remaining private at $t=1$. We present firms' decisions, first, for the benchmark case when investors can observe whether a firm is leader or not, and then for the case when investors are uninformed about firms' leading capabilities.

\footnotetext{
${ }^{1}$ We do not model choice of financing. That is, we focus on private firms that prefer public equity over private equity and bank loan.
} 
Proposition 1 If investors could observe firms' leading capabilities, owners of leaders and followers would retain $\alpha_{l}$ and $\alpha_{f}$ fraction of their firms in equilibrium respectively if they go public at $t=0$ :

$$
\begin{aligned}
\alpha_{l} & =\frac{A+q(1+(p+\Delta) f) V}{E+A+q(1+(p+\Delta) f) V} \\
\alpha_{f} & =\frac{A+q(1+p f) V}{E+A+q(1+p f) V}
\end{aligned}
$$

Given $\alpha_{l}$ and $\alpha_{f}$, the expected net payoffs of going public at $t=0$ for leaders and followers are $\pi_{l}$ and $\pi_{f}$ respectively, where:

$$
\begin{aligned}
& \pi_{l}=q(1+(p+\Delta) f) V-c \\
& \pi_{f}=q(1+p f) V-c
\end{aligned}
$$

The expected net payoff of waiting at $t=0$ for leaders and followers is $\pi_{1}$, such that:

$$
\pi_{1}=q(1+p f) V-q c
$$

At $t=0$, followers always wait. Leaders also wait if $\Delta<\Delta^{*}$, but go public if $\Delta \geq \Delta^{*}$ :

$$
\Delta^{*}=\frac{1-q}{q} \frac{c}{f V}
$$

At $t=1$, firms go public if the state of economy is good, and remain private otherwise. The shares are fairly priced.

Proof. See the Appendix. 
The intuition of Proposition 1 is as follows. If a follower goes public at $t=0$, it incurs the issuing costs $c$. In return, contingent on the state of economy, it gains access to a project at $t=1$, which has an expected net present value (NPV) of $q(1+p f) V$ at $t=0$. The follower appropriates all of this value, since investors merely break even on their equity investment $E$. Therefore, the follower's expected net payoff is the difference between $q(1+p f) V$ and $c$. If the follower, on the other hand, waits at $t=0$, the expected NPV of project is still the same, but the issuing costs are incurred only if the economy is good, since the net payoff of going public in a poor economy is negative, and the follower remains private in that state. This means that the follower has an option to go public. At $t=0$, it is better off by keeping this option alive in order to avert issuing costs, in case the economy turns out to be poor at $t=1$ (i.e. $\left.\pi_{f}<\pi_{1}\right) .^{2}$

Similarly, if a leader goes public at $t=0$, it incurs the issuing costs $c$. In return, if the economy turns out to be good at $t=1$, it invests in a project that has an expected NPV of $q(1+(p+\Delta) f) V$ at $t=0$. Thus, the leader's expected net payoff is the difference between $q(1+(p+\Delta) f) V$ and $c$. The leader faces a tradeoff between moving first to increase its probability of investing in the high-growth project and waiting until the resolution of uncertainty over the state of economy. It prefers to keep its option to go public alive if $\Delta$ is lower than $\Delta^{*}$ (i.e. $\pi_{l}<\pi_{1}$ for $\Delta<\Delta^{*}$ ). In this case, the risk of going public in an uncertain economic environment exceeds the benefit of being a first-mover. On the other hand, it exercises its option if $\Delta$ exceeds $\Delta^{*}$, in which case the first-mover advantage is valuable enough to justify going public early (i.e. $\pi_{l} \geq \pi_{1}$ for $\Delta \geq \Delta^{*}$ ).

\footnotetext{
${ }^{2}$ Note that in the absence of issuing costs, the follower is indifferent between going public or waiting at $t=0$, since $\pi_{f}=\pi_{1}$ for $c=0$.
} 
The value of $\Delta^{*}$ is sensitive to $c, f$, and $q$. Leaders have stronger incentives to move early when costs of going public are smaller $\left(\partial \Delta^{*} / \partial c>0\right)$. This is because, when issuing costs are lower, leaders lose less if the economy turns out to be poor at $t=1$. They, on the other hand, have weaker incentives to conduct an IPO at $t=0$ when $f$ is small $\left(\partial \Delta^{*} / \partial f<0\right)$. This means that when the spread between the values of high- and low-growth projects shrinks, moving early to have access to the former type of project becomes less attractive. Finally, leaders are more likely to capitalize on their first-mover advantage when the probability of having a good economy at $t=1$ is higher $\left(\partial \Delta^{*} / \partial q<0\right)$. Projects add value only in the good state, hence there is not much point of going public early to increase the chances of having access to a better project, if the economy is likely to be in the poor state.

Proposition 2 When investors cannot observe the leading capabilities of firms, Proposition 1 holds if $\Delta<\Delta^{* *}$, where:

$$
\Delta^{* *}=\frac{1-q}{q} \frac{c}{\left(1-\alpha_{s}\right) f V}>\Delta^{*}
$$

and

$$
\alpha_{s}=\frac{(1-q) c+A+q(1+p f) V}{E+A+q(1+p f) V}
$$

If $\Delta \geq \Delta^{* *}$, owners of leaders and followers both retain $\alpha_{s}$ fraction of their firms in equilibrium respectively if they go public at $t=0$, such that $\alpha_{f}<\alpha_{s}<\alpha_{l}$. Given $\alpha_{s}$, the expected net payoffs of going public at $t=0$ for leaders and followers are $\pi_{l, s}$ and $\pi_{f, s}$ respectively, 
where:

$$
\begin{aligned}
\pi_{l, s} & =q\left(1+\left(p+\frac{\Delta}{E+A+q(1+p f) V}\right) f\right) V-q c \\
\pi_{f, s} & =q(1+p f) V-q c
\end{aligned}
$$

The expected net payoff of going public at $t=1$ for leaders and followers is $\pi_{1}$ (see Equation 5).

At $t=0$, followers always wait and leaders always go public. At $t=1$, followers go public if the state of economy is good, and remain private otherwise. The shares of leaders are underpriced, while those of followers are fairly priced.

Proof. See the Appendix.

Proposition 1 holds even when investors cannot tell leaders apart from followers, as long as $\Delta<\Delta^{* *}$. This is because, in such a case, followers have no incentives to go public at $t=0$. Investors anticipate that only leaders would go public at $t=0$. In other words, only leaders would risk going public early to capitalize on their first-mover advantage. Therefore, at $t=0$, investors offer all firms that go public an ownership stake of $\alpha_{l}$. If $\Delta \geq \Delta^{* *}$, however, followers have an incentive to mimic leaders. This is because, when $\Delta$ exceeds $\Delta^{* *}$, $\alpha_{l}$ is sufficiently larger than $\alpha_{f}$ to justify pooling with leaders at $t=0$. The problem is, investors cannot offer all the firms $\alpha_{l}$ in equilibrium, if they anticipate that followers would pool at $t=0$. The reason is, if followers also go public at $t=0$, leaders cannot preempt them, and consequently lose their first-mover advantage. In other words, their probability of investing in the high-growth project falls back to $p$, and investors' rationality constraint is violated for $\alpha=\alpha_{l}$. For, $\alpha=\alpha_{s}<\alpha_{l}$, a separating equilibrium exists in which leaders 
go public and followers wait at $t=0 . \alpha_{s}$ is the maximum stake leaders can have, without motivating followers to pool at $t=0$ (i.e. $\pi_{f, s} \leq \pi_{1}$ for $\alpha \leq \alpha_{s}$ ). ${ }^{3}$ Leaders prefer going public at $t=0$, if investors offer them $\alpha_{s}$ (i.e. $\pi_{l, s}>\pi_{1}$ for $\alpha=\alpha_{s}$ ). Their shares are underpriced, however, since $\alpha_{s}<\alpha_{l}$.

To sum up, followers have incentives to mimic leaders when $\Delta$ is high, since $\alpha_{l}$, the ownership stake offered by investors to leaders, increases as $\Delta$ increases. Leaders, however, lose their first-mover advantage if followers mimic them. In such a case, they are willing to accept $\alpha_{s}$, which is lower than $\alpha_{l}$, to separate themselves from followers. This is because, the first-mover advantage is highly valuable for high values of $\Delta$. Therefore, when $\Delta$ is high, leaders' incentives to be first-movers are as strong as those of followers' to mimic leaders. Thus, leaders accept issuing underpriced shares in order to preempt followers.

We illustrate the outcomes of our model in Figure 3. At $t=0$, followers wait. Leaders also wait and lose their advantage if $\Delta<\Delta^{*}$. If the economy turns out to be poor at $t=1$, all firms remain private $(\operatorname{cold}$, cold). If the economy turns out to be good at $t=1$, however, all firms go public (cold, hot). In this case, they have access to the high-growth project with probability $p$, and their shares are fairly priced. At $t=0$, leaders go public if $\Delta \geq \Delta^{*}$. Their shares are underpriced if $\Delta \geq \Delta^{* *}>\Delta^{*}$. If the economy turns out to be poor at $t=1$, followers remain private (hot, cold). Finally, if the economy turns out to be good at $t=1$, followers also go public (hot,hot). Now, leaders have a higher chance of investing in the high-growth project. The shares of followers are fairly priced.

\footnotetext{
${ }^{3}$ We assume that when followers are indifferent in terms of IPO timing, they wait. Alternatively, we can assume investors offer an ownership stake of $\alpha_{s}-\epsilon$ at $t=0$, where $\epsilon$ is an arbitrarily small positive number. In this case, leaders would still go public at $t=0$ and followers at $t=1$.
} 


\subsection{Testable Hypotheses}

We develop testable hypotheses based on the (hot, hot) pair of Figure 3. Our interest in this pair is due to the fact that it is the only pair that gives rise to leaders and followers in a hot market.

Our model suggests that leaders go public early with an objective of boosting their probability of investing in the better project. In the case of (hot, hot) pair, they meet their objective, since the economy turns out to be good at $t=1$. Therefore, we expect firms that lead a hot market to have more valuable investment opportunities on average. We also expect their shares to be underpriced more on average, since investors cannot offer them the full value of their shares in equilibrium. These predictions lead to our first hypothesis $H 1$.

H1: Firms that lead a hot market have more valuable investment opportunities, and their issues are underpriced more severely on average.

This hypothesis is consistent with the findings of both Pastor and Veronesi (2005) and Lowry and Schwert (2002). The former paper shows that IPO volume responds to changes in market conditions. Hot markets in our model, also, emerge when the economy is (likely) to be good at $t=1$ (see the (hot, cold), (cold, hot), and (hot, hot) pairs of Figure 3), and cold markets prevail when the economy is (likely) to be poor at $t=1$ (see the (cold, cold) pair of Figure 3). The latter paper shows that more firms go public following periods of high underpricing, and argues that this is because underpricing is related to the positive information learned during the registration periods of early IPOs. In our paper, leaders content with issuing underpriced shares if they know that the economy is likely to be good in future, so that they will enjoy a first-mover advantage. Therefore, in a way, the current level of underpricing signals the future state of economy. 
Another suggestion of our model is that, investors cannot observe whether a firm is a leader or a follower. If they could, there would be no underpricing, since they would have demanded a lower ownership stake that fairly prices the leaders. As a result, we do not expect to see stark differences between the pre-IPO characteristics of leaders and followers. If the leaders had highly distinctive features, it would not have been hard for investors to tell them apart from the followers. On the other hand, we expect leaders to display significantly stronger growth and better stock performance after their issues, owing to their higher chance of investing in the high-growth project. Thus, we formulate our second hypothesis $H 2$ as follows:

H2: Leaders and followers cannot be identified by their pre-IPO firm characteristics, but can be distinguished in terms of their post-IPO growth and stock performance.

$H 2$ is in agreement with the findings of Helwege and Liang (2004) that hot and cold IPO firms have similar characteristics at the time of their issues. They also find that hot IPO firms do not display a better operating performance than cold IPO firms following their issues. We, however, argue that leaders in a hot market would exhibit stronger growth following their issues.

\section{Tests}

The purpose of this section is to test the hypotheses developed in Section 3.2. These hypotheses require that hot markets should last long enough to distinguish between leaders and followers. In other words, we are not interested in the short hot markets, which correspond to the $($ hot, cold) and the (cold, hot) pairs of Figure 3, but want to test whether early and 
late IPOs of long hot markets, which correspond to the (hot, hot) pair of Figure 3, differ from each other in accordance with our hypotheses. Consequently, we analyze hot markets that last at least 12 months. We identify leaders as firms that went public in the first half of a hot market, and followers as those that conducted their IPOs in the second half of a hot market.

Our empirical tests, as in Alti (2006), are conducted in IPO time. We define the fiscal year during which a firm went public as Year 0 for that firm. This is the firm's IPO year, and all other fiscal years are defined relative to it. For instance, the fiscal year preceding the IPO year is defined as Year-1, and the one that follows it as Year 1.

The rest of this section is structured as follows. We, first, explain our hot market definition (Section 4.1). Then, we describe our data (Section 4.2). Finally, we perform univariate (Section 4.3) and multivariate (Section 4.4) tests on our sample, and compare the long-run stock returns of leaders and followers (Section 4.5).

\subsection{Hot Market Definition}

The definition of a hot market varies across papers. This has the implication that the same month can be classified as hot (or cold) in one paper, and neutral in another. ${ }^{4}$ Moreover, the classification of a month as hot, neutral, or cold depends not only on the hot market definition, but also on the sample period and composition. In this section, we first show that existing hot market definitions are not robust to the length of sample period, and then propose a new definition.

We focus on two main definitions currently used in the literature. The first is by Alti

\footnotetext{
${ }^{4}$ One can argue that the variations in hot market definition is not so important because the classification of months with very high and very low IPO volume would be the same under different definitions. Although, it is true that there is no difficulty in classifying months with extremely high (low) volume as hot (cold), classification of the remaining months with non-extreme volumes is nontrivial. These months contain the bulk of IPOs, hence their correct classification is crucial for making the right inferences.
} 
(2006) and the second by Helwege and Liang (2004). Both definitions rank months in terms of their 3-month centered moving average of IPO volume (ma(3)). Alti (2006) defines a month as hot (cold), if that month is ranked above (below) the median month of the sample. Helwege and Liang (2004) define a month as hot (cold), if that month is ranked within the top quarter (bottom third) of the sample. Moreover, they restrict hot periods to last at least three months, while Alti (2006) does not have this restriction. ${ }^{5}$ In both papers, monthly IPO volume is deflated to account for growth. ${ }^{6}$

We, first, apply the definition and the sample selection criteria (spinoffs, unit offers, and financial firms are excluded) of Alti (2006) to identify hot markets in our sample period (January 1, 1970 - December 31, 2008) and in his sample period (January 1, 1971 - December 31, 1999). The results are displayed in Figure $1 \mathrm{a}$ and $1 \mathrm{~b}$ respectively. ${ }^{7}$ There are significant differences between the two plots. The extension of sample period to include 2000s causes 42 months that were initially classified as cold to be classified as hot. Most notably, almost the entire period from the start of 1991 to the end of 2000 is classified as a hot market in our sample period. This does not abide well with the argument that firms seize temporary windows of opportunity to go public in a hot market, as the window in this case remains open for a nearly uninterrupted period of 10 years. The reason for the differences in classification is the decrease in the volume of median month. For the sample period that ends in December 31, 1999, the median month has an ma(3) of 9.49 IPOs. After the extension of sample period, the median falls to 6.21 IPOs. This causes months that have between 6.21 and 9.49 IPOs to

\footnotetext{
${ }^{5}$ Pastor and Veronesi (2005) provide a slightly different hot market definition. They also rank months in terms of their $m a(3)$. As in Helwege and Liang (2004), they define a month as hot, if that month is ranked within the top quarter of the sample, and as in Alti (2006), they do not restrict hot periods to last at least 3 months.

${ }^{6}$ Lowry (2003) finds evidence that IPO volume is nonstationary over time. Thus, she detrends the volume by deflating it.

${ }^{7}$ Our Figure 1b corresponds to Figure 1 in Alti (2006).
} 
be classified as hot in the longer sample period, while they were initially identified as cold months.

Now, we turn our attention to the definition of Helwege and Liang (2004). Figure 2a and $2 \mathrm{~b}$ show hot markets according to their definition and sample selection criteria (spinoffs, reverse LBOs, IPOs with offer prices less than $\$ 1$, and financial firms are excluded) in our and their sample period (January 1, 1975 - December 31, 2000) respectively. ${ }^{8}$ The extension of sample period again leads to many differences in classification. The cold market in early 1985 disappears, some of the months that were cold between 1988 and 1991 become neutral, a new hot market appears in 1991 and another in 1997. Overall, 43 months are classified differently as a result of extending the sample period to include the first half of 1970 s and the 2000s. The reason again is the change in thresholds used for classification. The upper and lower thresholds fall from 32.23 and 11.64 IPOs to 28 and 7.89 IPOs respectively. Consequently, months that have less than 32.23 , but more than 28 IPOs become hot, and those that have less than 11.64, but more than 7.89 IPOs become neutral in our longer sample period.

The main conclusion from our analysis of existing hot market definitions is that, existing hot market definitions are not robust to the length of sample period. Therefore, we propose a new definition in order to overcome this problem. We, first, deflate the monthly IPO volume by the number of public firms at the end of previous month to correct for nonstationarity (see Pastor and Veronesi (2005) for an identical treatment). Then, we calculate a "short-run" and a "long-run" centered moving average of deflated IPO volume $\left(m a_{s}\right.$ and $\left.m a_{l}\right)$. Finally, we classify a month as hot, if $m a_{s}$ of that month is sufficiently higher than $m a_{l}$ (i.e. if $m a_{s}$ exceeds $m a_{l}$ plus a mark-up).

Our definition contains three parameters: the length of short-run moving average, the

\footnotetext{
${ }^{8}$ Our Figure 2b corresponds to Figure 1 in Helwege and Liang (2004).
} 
length of long-run moving average, and the mark-up. Alti (2006), Helwege and Liang (2004), and Pastor and Veronesi (2005)) use a 3-month centered moving average. Yung, Colak, and Wang (2008) argue that grouping IPOs into yearly cohorts is too coarse and into monthly groups is too fine. Therefore, they decide to group them into quarters and take a 4-quarter moving average. We choose 6 months and 3 years as the lengths of our short- and long-run centered moving averages and set the mark-up to 1 IPO. That is, we classify a month as hot if its 6-month centered moving average of deflated IPO volume exceeds its 3-year centered moving average of deflated IPO volume by at least 1 IPO.

We check whether our proposed definition is indeed robust to the sample period, by identifying hot markets using our definition in three different sample periods (ours, and those of Alti (2006) and Helwege and Liang (2004)). We find that all overlapping months in our and in Alti (2006)'s sample have the same classification, and only 5 of the months that are in our and in Helwege and Liang (2004)'s sample are classified differently. This is substantial improvement over the existing definitions, considering that they classify more than 40 months differently. The robustness of our definition is due to the fact that extension of sample period has very little impact on a month's long-run moving average of deflated IPO volume. As a result, we use this definition to determine hot markets in our sample period.

\subsection{Data}

Our dataset, which is obtained from Securities Data Company (SDC), contains 12,007 common share IPOs that took place in the U.S. between January 1st, 1970 and December 31st, 2008. We construct our initial sample from this dataset by dropping IPOs by financial firms (2,670 observations), reverse leveraged buyouts (299 observations), spinoffs (572 observa- 
tions), IPOs with an offer price less than $\$ 1$ (141 observations), IPOs that have duplicate CUSIP codes (28 observations), and unit offers (1,011 observations). ${ }^{9}$ Consequently, there are 7,286 observations in our initial sample. We identify 1,918 and 2,111 of these observations as IPOs conducted by leaders and followers in a hot market respectively. The remaining IPOs take place either in cold markets or in hot markets that last less than a year.

We get offer prices, numbers of primary and secondary shares, amounts of total proceeds, and information on venture capital backing from SDC, which has data for all of our early and late IPOs. We obtain the first trading day closing prices from Center for Research in Securities Prices (CRSP). We drop observations if the trading date is 2 days earlier or 10 days later than the IPO date. 1,614 leaders and 1,812 followers in our initial sample have price data. ${ }^{10}$ We collect financial data from Compustat. We drop observations if data for the fiscal year preceding the IPO year (i.e. Year -1) is missing. 1,413 leaders and 1,556 followers in our sample have financial data. Finally, we get the firm foundation years from Field-Ritter dataset. ${ }^{11}$ 1,595 leaders and 1,792 followers in our sample have foundation year data.

The variables that we use in our tests are defined as follows. IniR is the initial return of an IPO. It is the percentage change from the offer price to the first trading day closing price. PSec is the secondary shares offered as a percentage of total shares offered. TPro is the total proceeds raised as a percentage of the value of total assets in Year 0. VCap is a dummy variable that is equal to 1 if an IPO firm is backed by a venture capital firm. Mto $B_{i}$ is the market to book ratio in Year $i$. It is equal to the value of book debt (the long-term

\footnotetext{
${ }^{9}$ Our sample selection criteria are similar to those employed by Helwege and Liang (2004).

${ }^{10} \mathrm{CRSP}$ starts providing prices on NASDAQ stocks in December 1972. Most of the observations we drop are the IPOs that took place between January 1970 and December 1972.

${ }^{11}$ See Jay Ritter's website: http://bear.warrington.ufl.edu/ritter/FoundingDates.htm
} 
debt in Year $i$ ) plus the value of market equity (the number of common shares outstanding times the share price in Year $i$ ) divided by the value of total assets in Year $i$. Sales and $A_{s s e t} s_{i}$ are net sales and total assets in Year $i$ respectively. $\Delta$ Sales $_{i}$ and $\Delta$ Assets $_{i}$ are percentage growths in net sales and total assets from Year -1 to Year $i$ respectively. Net sales and total assets are in millions of 2008 dollars. Debt $t_{i}$ is long-term debt, Prof $f_{i}$ is EBITDA, and $\operatorname{Cap} X_{i}$ is capital expenditures in Year $i$ as a percentage of the value of total assets in $Y e a r i . \Delta D_{e b t}, \Delta \operatorname{Prof}_{i}$, and $\Delta C a p X_{i}$ are percentage changes in long-term debt, EBITDA, and capital expenditures from Year -1 to Year $i$ respectively. Age is the difference between the IPO year and the foundation year of a firm. All variables are winsorized at $5 \%$, except $V C a p, S_{a l e s}, A_{s s e t}$, and Age. The last three of the unwinsorized variables are in natural logarithms. In the case of Age, we add 1 to each observation when taking the natural logarithm to eliminate the cases of $\ln (0) \cdot{ }^{12}$ Finally, the binary variable $L$ takes the value of 0 (1) if the IPO is conducted by a leader (follower).

\subsection{Univariate Tests}

We, first, test our hypotheses (see Section 3.2) in terms of univariate sorts. Table 1 provides descriptive statistics for the 9 hot markets that lasted at least a year during our sample period. The lengths of these hot markets range from 12 to 18 months and the average length of a hot market is 15 months. The numbers of leaders and followers in a hot market do not differ significantly from each other. Overall, there are 1,918 leaders and 2,111 followers.

In Panel A, the last column shows that shares of leaders are underpriced approximately $7 \%$ more. Moreover, this difference is not driven by a single hot market, and is present in most of the hot markets. In particular, underpricing was significantly worse for leaders in

\footnotetext{
${ }^{12}$ See Loughran and Ritter (2004) for the same treatment.
} 
the 1st, 2nd, 3rd, 6th, 7th, and 8th hot markets. The last column of Panel B shows that the average market to book ratio of leaders exceeds that of followers roughly by 1 . Furthermore, this difference again is not driven by a single market. Leaders of the 2nd, 3rd, 4th, 5th, 6th, 7th, and 8th hot markets have higher market to book ratios on average than followers. These figures support our first hypothesis $H 1$. That is, firms lead a hot market to boost their chances of investing in more valuable growth opportunities, which are proxied by market to book ratio, at the cost of higher underpricing.

Panels C, D, E, and F report descriptive statistics on variables that we use as controls in our multivariate tests (Section 4.4). The leaders offer slightly more secondary shares as a percentage of total shares. In the $3 \mathrm{rd}, 8 \mathrm{th}$, and 9 th hot markets leaders, and in the 2nd and 5th hot markets followers raise significantly more total proceeds scaled by total assets in Year 0 . Therefore, there is no clear cut difference between leaders and followers in terms of the amount of total proceeds they raise. Leaders and followers do not differ much in terms of their venture capital backing frequency and their age at the time of their IPOs.

Table 2 provides descriptive statistics for the leading and the following IPO firms in our sample. The net sales of leaders are no different than those of followers in the fiscal year that precedes their IPO year $\left(\right.$ Sales $\left._{-1}\right)$. They, however, grow faster in the IPO year and in the following two fiscal years $\left(\Delta\right.$ Sales $_{0}$ through $\Delta$ Sales $\left._{2}\right)$. The total assets of leaders are slightly lower in Year - 1. They, also, grow faster in the IPO year and in the following fiscal years $\left(\Delta\right.$ Assets $_{0}$ through $\Delta$ Assets $\left._{3}\right)$. As a result, ex-post total assets $\left(\right.$ Assets $_{0}$ through Assets $\left._{3}\right)$ and net sales $\left(\right.$ Sales $_{0}$ through Sales $_{3}$ ) of leaders exceed those of followers, even though leaders have less total assets and same amount of net sales ex-ante.

The leaders make higher capital expenditures before and after their IPO year $\left(\operatorname{Cap}_{-1}\right.$ 
and $\operatorname{Cap} X_{1}$ ). Moreover, they experience a significantly stronger growth (more than $100 \%$ ) in capital expenditures in $Y$ ear $1\left(\Delta C a p X_{1}\right)$. In terms of profitability, leaders and followers are equivalent up to Year 2. In Year 3, leaders become more profitable than followers. In terms of EBITDA growth, on the other hand, leaders surpass followers in particular in the first two fiscal years that follow their IPO year $\left(\Delta \operatorname{Prof}_{1}\right.$ and $\left.\Delta \operatorname{Prof}_{2}\right)$. Finally, leaders and followers do not differ in terms of their long-term debt level between Year -1 and Year 3. Leaders have a slightly higher net debt issuance in their IPO year $\left(\Delta D e b t_{0}\right)$, but otherwise their net debt issuance is the same as followers.

Overall, the figures in Table 2 show that leaders experience stronger growth in net sales, total assets, capital expenditures, and EBITDA, especially immediately after their IPOs in Year 1. This is despite the fact that the levels of these variables (except $C_{a p} X_{-1}$ ) are the same for leaders and followers in Year -1 . These findings are consistent with our second hypothesis $H 2$ : Leaders and followers have similar ex-ante characteristics, but leaders experience stronger growth ex-post.

\subsection{Multivariate Tests}

We, now, test our hypotheses (see Section 3.2) in a multivariate setting. We start by analyzing whether leading firms of hot markets suffer from higher underpricing and whether they have higher market to book ratios in their IPO year after controlling for firm and issue characteristics. In particular, we regress first $\operatorname{IniR}$ and then $M t o B_{0}$ on a binary variable that takes the value of 1 if the firm is a leader $L$ and a set of control variables. The control variables are size (proxied by Sales $_{-1}$, Assets $_{-1}$ or Age), leverage (proxied by Debt-1), profitability (proxied by $\operatorname{Prof}_{-1}$ ), investment (proxied by $\operatorname{CapX}_{-1}$ ), venture capital backing 
$(V C a p)$, secondary shares $(P S e c)$, total proceeds (TPro), and industry fixed effects (set of dummies $d$ Ind):

$$
\begin{gathered}
Y=\beta_{0}+\beta_{1} L+\beta_{2} \text { Size }_{-1}+\beta_{3} \text { Debt }_{-1}+\beta_{4} \text { Prof }_{-1}+\beta_{5} \text { CapX }_{-1} \\
+\beta_{6} \text { VCap }+\beta_{7} \text { PSec }+\beta_{8} \text { TPro }+\beta_{9} d \text { Ind }+\epsilon, \quad Y \in\left\{{\text { IniR }, M t o B_{0}}\right\}
\end{gathered}
$$

The results of our regressions are presented in Table 3. In Models (1)-(3), underpricing is the dependent variable. In a univariate setting, IPOs of leaders are underpriced roughly $7 \%$ more on average (see Panel A in Table 1). In a multivariate setting, firm, issue, and industry characteristics can only explain approximately 2.5 to $2.8 \%$ of this difference and IPOs of leaders are still underpriced 4.2 to $4.5 \%$ more on average. In Models (4)-(6), market to book ratio is the dependent variable. Leaders' market to book ratios in Year 0 exceed those of followers by 1 , in a univariate setting. In a multivariate setting, 0.67 to 0.73 of this difference is due to being a leader, and control variables only explain 0.27 to 0.33 of it. Therefore, our first hypothesis $H 1$ is supported in a multivariate as well as in a univariate setting. Being a leader in a hot market has explanatory power on IPO underpricing and market to book ratios in the IPO year, after controlling for firm, industry, and issue characteristics.

We, next, investigate whether pre-IPO characteristics of firms can explain whether they become leaders and followers, and whether leaders display stronger post-IPO growth. To this end, we first regress the binary variable $L$ on the control variables that we used in Equation 11:

$$
\begin{gathered}
L=b_{0}+b_{1} \text { Size }_{-1}+b_{2} \text { Debt }_{-1}+b_{3} \text { Prof }_{-1}+b_{4} \text { CapX }_{-1} \\
+b_{5} \text { VCap }+b_{6} \text { PSec }+b_{7} \text { TPro }+b_{8} d \text { Ind }+\epsilon, \quad Y \in\left\{\text { IniR, MtoB } B_{0}\right\}
\end{gathered}
$$


The results of this regression in presented in Model (1) of Table 4. The coefficients of Assets $_{-1}$, Debt $_{-1}$, Prof $_{-1}, V C a p$, and TPro are insignificant. The coefficient of CapX $_{-1}$ is barely significant at $9.8 \%$ significance level, and its value is quite small. $P S e c$ has a statistically significant, yet a small, coefficient. The insignificant coefficients of other variables justify our claim in $H 1$ that leaders cannot be distinguished from followers in terms of preIPO characteristics. The results are similar when Sales $_{-1}$ or Age is used as a proxy of size instead of Assets $_{-1}$.

Finally, we check whether the differences between the post-IPO growth of leaders and followers that we observed in a univariate setting still remain in a multivariate setting. Specifically, we regress the changes in sales, assets, investment, profitability, and leverage from Year -1 to Year 1 on our binary variable $L$, and the control variables that we have used in the previous models:

$$
\begin{aligned}
& Y=\beta_{0}+ \beta_{1} L+\beta_{2} \text { Size }_{-1}+\beta_{3} \text { Debt }_{-1}+\beta_{4} \text { Prof }_{-1}+\beta_{5} \text { CapX }_{-1} \\
&+\beta_{6} \text { VCap }+\beta_{7} \text { PSec }+\beta_{8} \text { TPro }+\beta_{9} d \text { Ind }+\epsilon \\
& Y \in\left\{\Delta \text { Sales }_{1}, \Delta \text { Assets }_{1}, \Delta \text { Cap }_{1}, \Delta \text { Prof }_{1}, \Delta \text { Debt }_{1}\right\}
\end{aligned}
$$

The results of these regressions are provided in Models (2) to (5) of Table 4. The coefficients of Assets $_{-1}$, Debt $_{-1}$, and Prof $f_{-1}$ are always negative and in the majority of cases significant. Their signs are consistent with the generic description of a growth firm: small, unlevered, and not profitable. Firms that make higher capital expenditures in Year - $1\left(\right.$ Cap $\left._{-1}\right)$ experience more growth in net sales and total assets in Year 1. Firms that are backed by venture capital partnerships ( $V C a p)$ display stronger sales and EBITDA growth. Firms that 
offer more secondary shares as a percentage of total shares (SPro) experience slightly weaker growth in net sales, total sales, and capital expenditure. The amount of total proceeds raised as a percentage of total asset (TPro) has a small negative effect on post-IPO growth. Finally, $L$, which is the main variable of our interest, has both statistically and economically significant positive coefficients in Models (2) to (5). Leaders in a hot market shift their postIPO net sales, total assets, capital expenditure, and EBITDA growths by 49.85\%, 109.85\%, $125.50 \%$, and $39.43 \%$ respectively. Thus, as we argue in our second hypothesis $H 2$, being a leader in a hot market has significant explanatory power on post-IPO growth. The results are, again, similar when Sales $_{-1}$ or Age is used as a proxy of size instead of Assets $_{-1}$.

\subsection{Long-run Stock Returns}

We compare long-run stock returns of leaders and followers as a final test of our second hypothesis $H 2$. This hypothesis argues that leaders should outperform followers, at least initially, since leaders are more likely to invest in more valuable investment opportunities.

We, first, calculate monthly buy-and-hold returns (BHRs) on each IPO stock up to 36 months. We start calculating the returns from the end of IPO month. If an IPO stock delists within 36 months of its issue, we carry its delisting month BHR to the remaining months, to control for sample selection bias.

We adjust BHRs of IPO stocks by using three different benchmarks. The first benchmark is equally weighted BHRs on all NYSE, AMEX, and NASDAQ stocks. The second benchmark is value weighted BHRs on the same set of stocks. The third benchmark is equally weighted BHRs on size portfolios. We rank all NYSE, AMEX, and NASDAQ stocks in terms of their market capitalization, and form five portfolios using quintiles of the ranking. We reform these 
portfolios each month. Then, we match each IPO stock to one of the five size portfolios, on the basis of its market capitalization one month after its issue.

We calculate buy-and-hold abnormal return (BHAR) for an IPO stock $i$ in a particular month $T$ as the difference between its BHR and the benchmark $b$ 's BHR for that month:

$$
\begin{aligned}
B H A R_{i, T} & =\prod_{t=1}^{T}\left(1+r_{i, t}\right)-\prod_{t=1}^{T}\left(1+r_{b, t}\right) \\
& =B H R_{i, T}-B H R_{b, T}
\end{aligned}
$$

where $r_{i, t}$ and $r_{b, t}$ are the returns on the IPO stock $i$ and the benchmark $b$ in month $t$ respectively.

Figure 5 illustrates mean BHARs for leaders and followers up to 36 months following their issues (i.e. $T \in[1,36])$. In Plot $5 \mathrm{a}(5 \mathrm{~b})$, the benchmark is the equally (value) weighted BHRs on all NYSE, AMEX, and NASDAQ stocks. In Plot 5c, it is the equally weighted BHRs on size portfolios formed from the same set of stocks. Followers underperform the market right from the start. Leaders outperform the market approximately for 9 months and the followers roughly for 15 months. These results are consistent with our findings that leaders display significantly stronger growth than followers, particularly, in the fiscal year that succeeds the IPO year (i.e. Year1) (see Table 2 in Section 4.3 and Table 4 in Section 4.4). They provide further evidence for our second hypothesis, which states that leaders can be distinguished from followers in terms of ex-post stock performance. 


\section{Conclusion}

The average numbers of firms that go public in the first and the second halves of a hot market are close to each other. This is despite the fact that underpricing is more severe during a hot market's first half. Therefore, it seems that many private firms are willing to bear additional underpricing, which is an indirect cost of going public, in order to lead a hot market.

In this paper, we provided a rationale for a private firm's willingness to become a leader in a hot market. We argued that firms have incentives to go public early if they can increase their chances of investing in a better project, which is short in supply, by preempting other firms.

We developed testable hypotheses based on our model's outcomes: (1) Leaders in a hot market suffer from higher underpricing, but gain access to more valuable investment opportunities. (2) Leaders and followers cannot be distinguished by their ex-ante characteristics, but differ in terms of their ex-post growth and stock performance.

We tested these hypotheses using a sample of IPOs that took place in the U.S. between 1970 and 2008. We identified hot markets using a definition that is robust to sample period length. We found evidence that supports our hypotheses: IPOs of leaders are underpriced more than those of followers, and leaders have higher market to book ratios in their IPO year. Leaders and followers do not differ in terms of pre-IPO characteristics, but leaders display stronger post-IPO growth in sales, asset, capital expenditure and EBITDA. Their shares outperform those of followers up to 15 months.

The main focus of hot markets literature so far has been the differences of IPOs between cold and hot markets. Consequently, the differences of IPOs within a hot market is not examined sufficiently, even though the bulk of IPO activity is in hot markets. Our paper 
contributes to the literature by pointing out the differences between early and late IPOs of a hot market, and by providing a rationale for IPO timing within a hot market.

\section{A Appendix}

Proof of Proposition 1. First, we derive $\alpha_{f}$ and $\pi_{f}$. At $t=1$, if the economy is in a good state, the follower is worth $A+E+(1+f) V$ with probability $p$, and $A+E+V$ with probability $1-p$. Otherwise, it is worth $A+E$. Thus, the expected worth of the follower at $t=0$ is $\left.W_{f} \equiv q(p(A+E+(1+f) V)+(1-p)(A+E+V))+(1-q)(A+E)\right)=A+E+q(1+p f) V$. Investors who hold $1-\alpha$ fraction of the firm after its IPO break even if $(1-\alpha) W_{f}=E$. Consequently, $\alpha_{f} \equiv(A+q(1+p f) V) /(A+E+q(1+p f) V)$. The expected net payoff of going public at $t=0$, then, is:

$$
\begin{aligned}
\pi_{f} & =\max \left[\alpha_{f} W_{f}-(A+c), 0\right] \\
& =q(1+p f) V-c
\end{aligned}
$$

Now, we derive $\alpha_{l}$ and $\pi_{l}$. At $t=1$, if the economy is in a good state, the leader is worth $A+E+(1+f) V$ with probability $p+\Delta$, and $A+E+V$ with probability $1-p-\Delta$. Otherwise, it is worth $A+E$. Thus, the expected worth of the leader at $t=0$ is $W_{l} \equiv$ $q((p+\Delta)(A+E+(1+f) V)+(1-p-\Delta)(A+E+V))+(1-q)(A+E)=A+E+q(1+(p+\Delta) f) V$. Investors who hold $1-\alpha$ fraction of the firm after its IPO break even if $(1-\alpha) W_{l}=E$. Consequently, $\alpha_{l} \equiv(A+q(1+(p+\Delta) f) V) /(A+E+q(1+(p+\Delta) f) V)$. The expected net 
payoff of going public at $t=0$, then, is:

$$
\begin{aligned}
\pi_{l} & =\max \left[\alpha_{l} W_{l}-(A+c), 0\right] \\
& =q(1+(p+\Delta) f) V-c
\end{aligned}
$$

Finally, we derive $\pi_{1}$. At $t=1$, if the economy is good and the high-profitability project is accessible, the firm is worth $W_{1, H} \equiv A+E+(1+f) V$. In this case, investors break even if $\left(1-\alpha_{1, H}\right) W_{1, H}=E$, which implies $\alpha_{1, H} \equiv(A+(1+f) V) /(A+E+(1+f) V)$. Owners' net payoff is $\pi_{1, H} \equiv \max \left[\alpha_{1, H} W_{1, H}-(A+c), 0\right]=(1+f) V-c$. If the economy is good and the high-profitability project is not accessible, the firm is worth $W_{1, L} \equiv A+E+V$. Investors, now, participate if $\left(1-\alpha_{1, L}\right) W_{1, L}=E$. This implies $\alpha_{1, L} \equiv(A+V) /(A+E+V)$. Owners' net payoff is $\pi_{1, L} \equiv \max \left[\alpha_{1, L} W_{1, L}-(A+c), 0\right]=V-c$. Finally, if the economy is poor, the firm is worth $W_{1, P} \equiv A+E$. Investors' breakeven condition is $\left(1-\alpha_{1, P}\right) W_{1, P}=E$, which yields $\alpha_{1, P} \equiv A /(A+E)$. Owners' net payoff is $\pi_{1, P} \equiv \max \left[\alpha_{1, P} W_{1, P}-(A+c), 0\right]=0$. Consequently, the expected net payoff of waiting at $t=0$ is:

$$
\begin{aligned}
\pi_{1} & =q\left(p \pi_{1, H}+(1-p) \pi_{1, L}\right)+(1-q) \pi_{1, P} \\
& =q(1+p f) V-q c
\end{aligned}
$$

Followers compare $\pi_{f}$ with $\pi_{1}$, and decide to wait at $t=0$, since the former payoff is smaller for $q<1$. At $t=1$, if the economy is good, they go public, since $\pi_{1, H}>0$ and 
$\pi_{1, L}>0$; and if it is poor, they remain private, since $\pi_{1, P}=0$. Leaders compare $\pi_{l}$ with $\pi_{1}$ :

$$
\begin{aligned}
\pi_{l} & \lessgtr \pi_{1} \\
q(1+(p+\Delta) f) V-c & \lessgtr q(1+p f) V-q c \\
q \Delta f V & \lessgtr(1-q) c \\
\Delta & \lessgtr \frac{1-q}{q} \frac{c}{f V} \equiv \Delta^{*}
\end{aligned}
$$

They go public if $\Delta \geq \Delta^{*}$, since $\pi_{l} \geq \pi_{1}$. Otherwise, $\pi_{l}<\pi_{1}$, and leaders wait at $t=0$. At $t=1$, if the economy is good, they go public, since $\pi_{1, H}>0$ and $\pi_{1, L}>0$; and if it is poor, they remain private, since $\pi_{1, P}=0$.

Proof of Proposition 2. Followers have an incentive to pool with leaders at $t=0$, if $\alpha_{l} W_{f}-(A+c)>\pi_{1}$. That is, if they pretend to be leaders they are offered $\alpha_{l}$, even though their expected worth is $W_{f}$, and not $W_{l}$. The inequality is satisfied if $\Delta>\Delta^{* *}$. The maximum stake that induces followers to wait solves $\alpha_{s} W_{f}-(A+c)=\pi_{1}$. For followers, the expected net payoff of going public at $t=0$ is:

$$
\begin{aligned}
\pi_{f, s} & =\max \left[\alpha_{s} W_{f}-(A+c), 0\right] \\
& =q(1+p f) V-q c
\end{aligned}
$$

For leaders, the expected net payoff of going public at $t=0$ is:

$$
\begin{aligned}
\pi_{l, s} & =\max \left[\alpha_{s} W_{l}-(A+c), 0\right] \\
& =q\left(1+\left(p+\frac{\Delta}{E+A+q(1+p f) V}\right) f\right) V-q c
\end{aligned}
$$


The expected net payoff of waiting at $t=0$ is still $\pi_{1}$ (See the Proof of Proposition 1).

Followers compare $\pi_{f, s}$ with $\pi_{1}$, and decide to wait at $t=0$, since the former payoff is less than or equal to the latter payoff. At $t=1$, if the economy is good, they go public, since $\pi_{1, H}>0$ and $\pi_{1, L}>0$; and if it is poor, they remain private, since $\pi_{1, P}=0$. Leaders compare $\pi_{l, s}$ with $\pi_{1}$, and decide to go public at $t=0$, since the former payoff exceeds the latter for $\Delta>0$. 


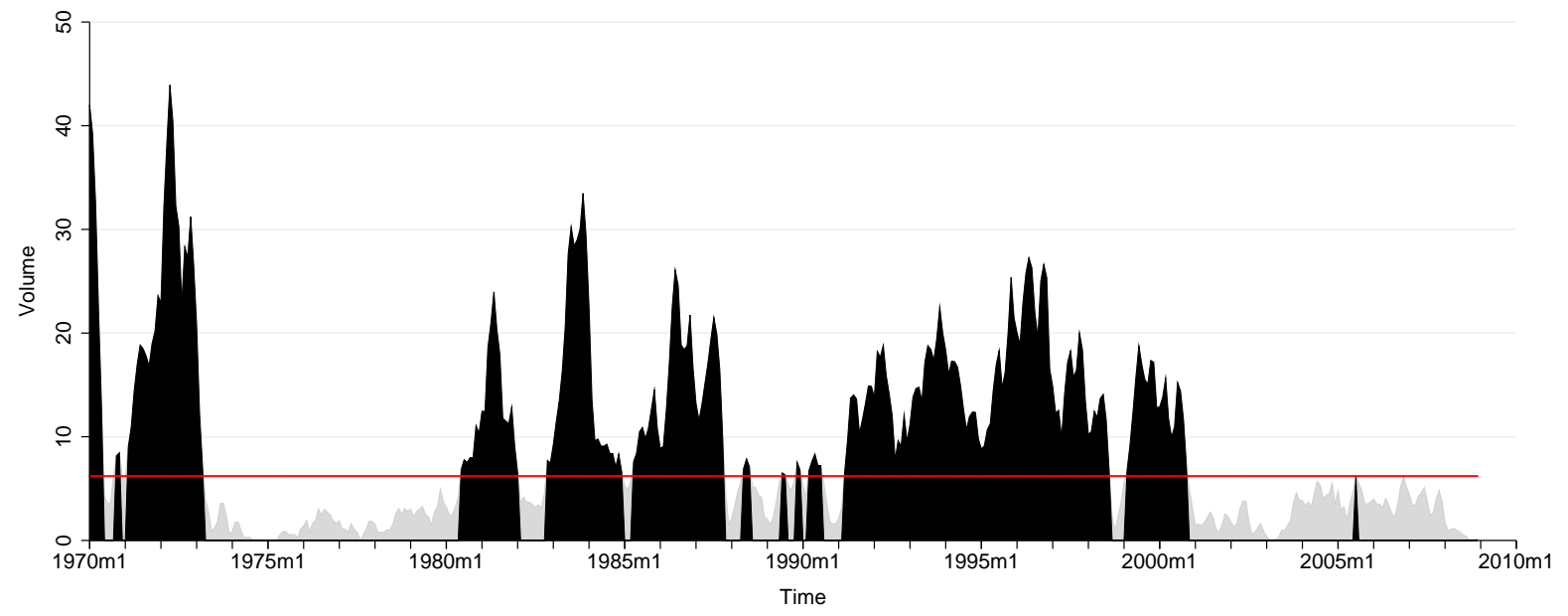

(a)

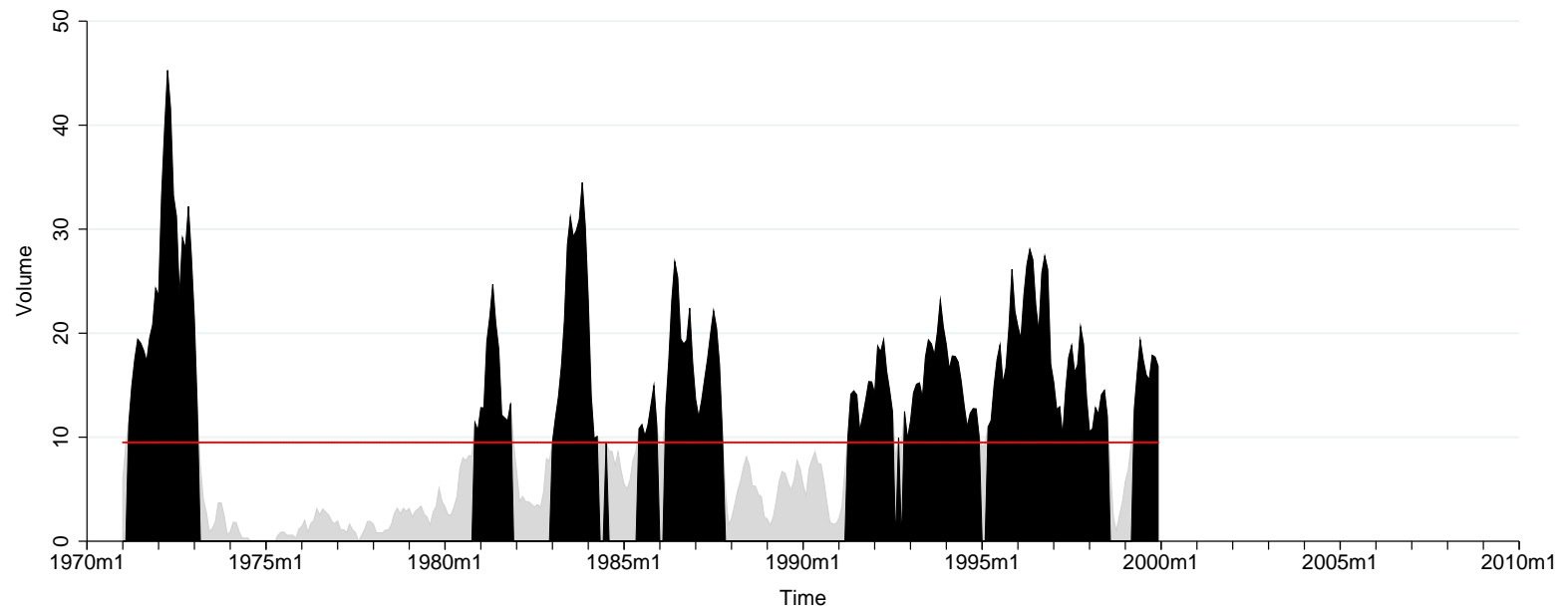

(b)

Figure 1. Hot markets according to the definition of Alti (2006). Figures 1a and 1b plot the detrended 3 -month centered moving average of monthly IPO volume during January 1, 1970 - December 31, 2008 and January 1, 1971 - December 31, 1999 respectively. The sample excludes spinoffs, unit offers, and financial firms. In both figures, the black (light gray) shaded areas represent the hot (cold) issue markets, during which ma(3) is above (below) the horizontal median line. 


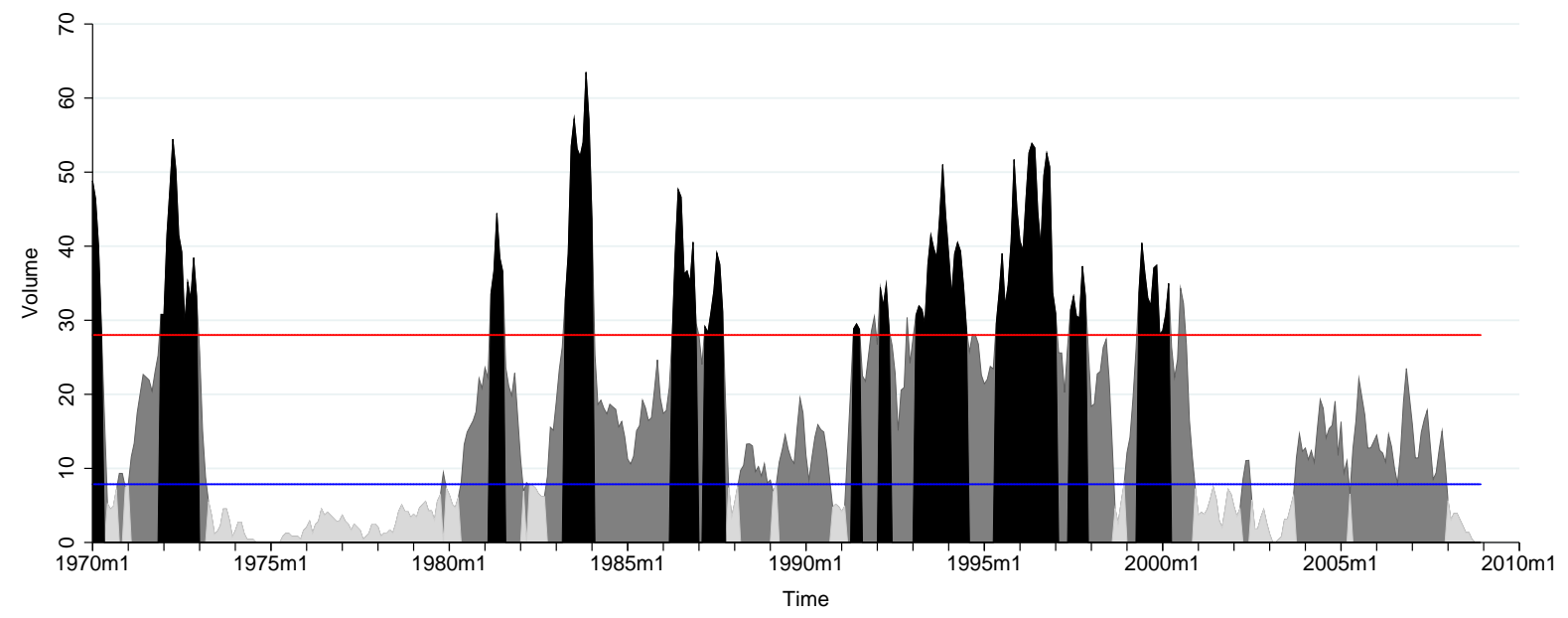

(a)

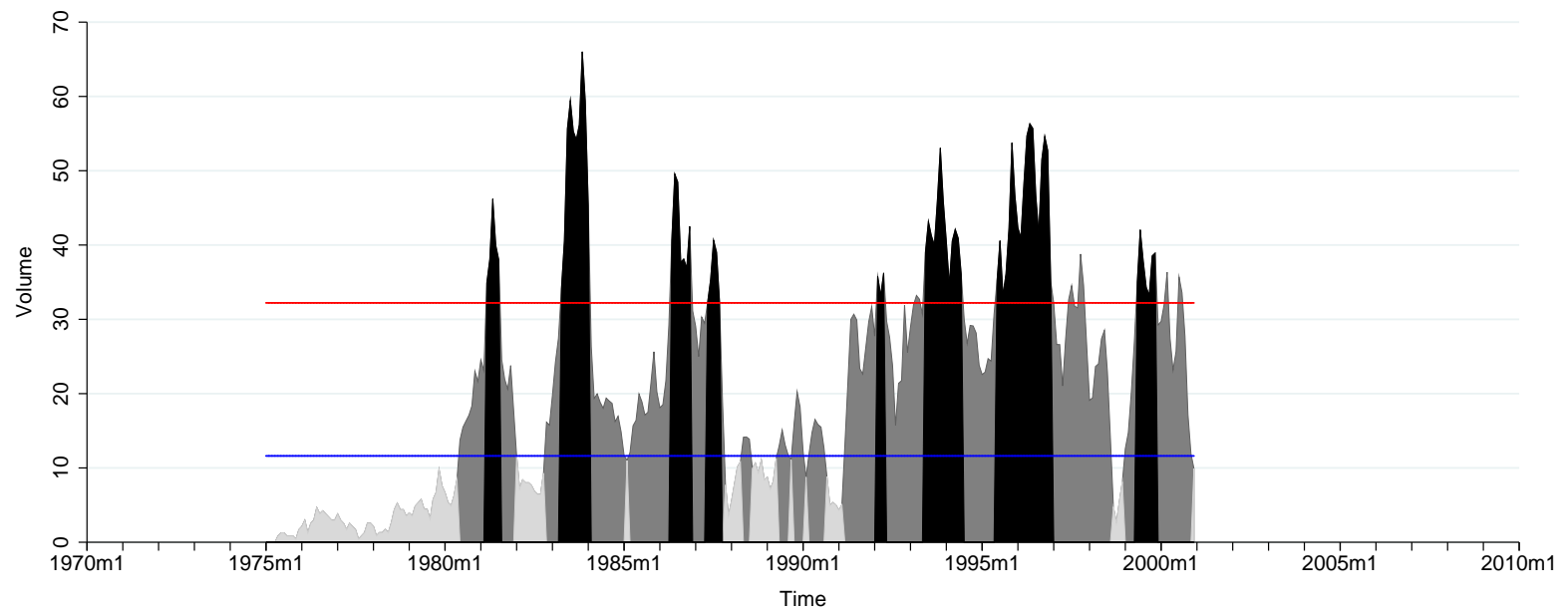

(b)

Figure 2. Hot markets according to the definition of Helwege and Liang (2004). Figures 2a and $2 \mathrm{~b}$ plot 3-month centered moving average of deflated monthly IPO volume during January 1, 1970 - December 31, 2008 and January 1, 1971 - December 31, 1999 respectively. The sample excludes spinoffs, reverse LBOs, IPOs with an offer price less than $\$ 1$, and financial firms. In both figures, the black (light gray) shaded areas represent hot (cold) markets, during which $m a(3)$ is above (below) the horizontal top quarter (bottom third) line. 


\begin{tabular}{l|cc} 
Economy & $\Delta<\Delta^{*}$ & $\Delta \geq \Delta^{*}$ \\
\hline poor & $($ cold, cold $)$ & $($ hot, cold $)$ \\
good & $($ cold, hot $)$ & $($ hot, hot $)$
\end{tabular}

Figure 3. Model outcome. The leftmost column shows the state of economy at $t=1$. In the middle and right columns, $\Delta$, the increase in the probability of having access to the high-growth project, is below or above its critical level $\Delta^{*}$ respectively. The pairs show the state of market at $t=0$ and $t=1$, depending on the state of economy at $t=1$ and the level of $\Delta$. There are no IPOs in a cold market. Firms go public in hot markets.

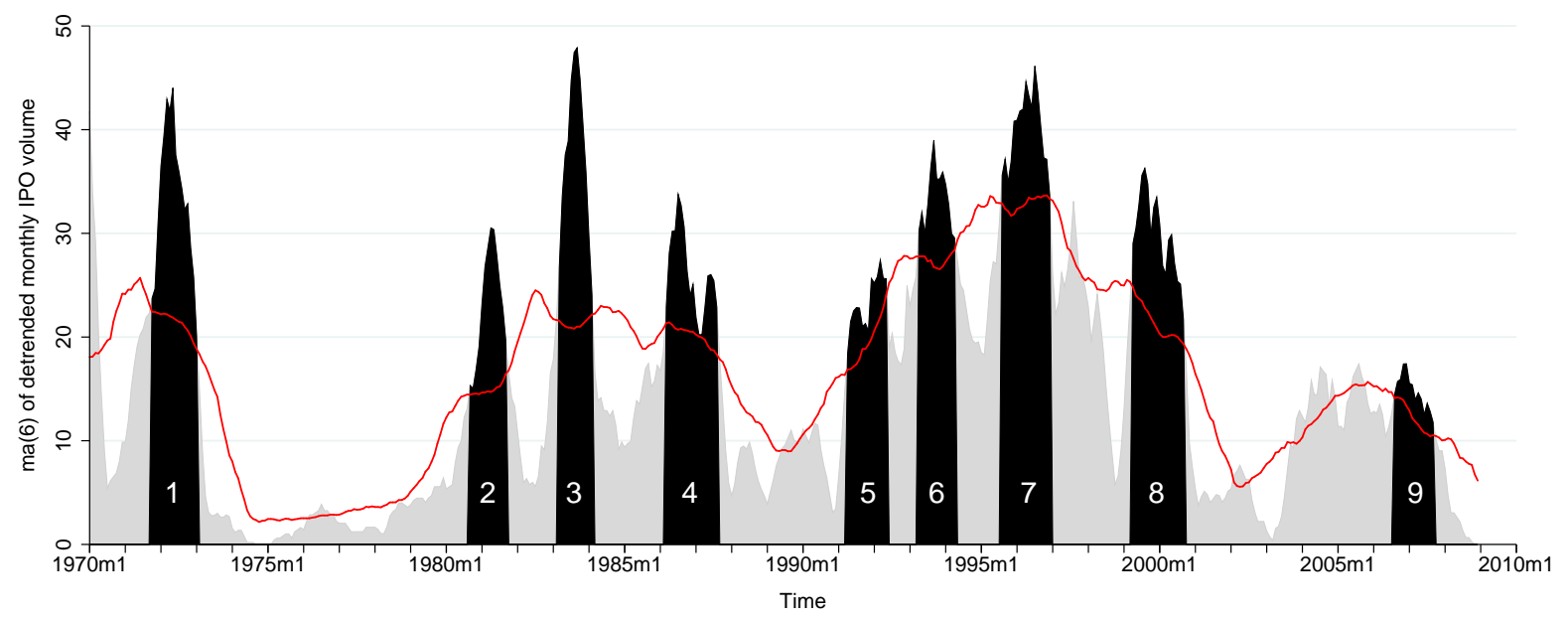

Figure 4. Hot markets. The line plot is the 3 year centered moving average of detrended monthly IPO volume (i.e. long-run volume). The area plot is the 6 month centered moving average of detrended monthly IPO volume (i.e. short-run volume). The numbered areas in black are the hot markets that last at least 1 year. The sample used to calculate detrended monthly IPO volume excludes financial firms, reverse LBOs, spinoffs, stocks that are issued at a price lower than $\$ 1$, observations with duplicate CUSIPs, and unit offers. 
Table 1. Descriptive Statistics for Hot Markets

Descriptive statistics for the 9 hot markets that were at least a year long and that took place between 1970 and 2008. The statistics are displayed separately under the columns 1-9, and jointly under the column "All". Length is the hot market length measured in months. $N_{L}$ and $N_{F}$ are the numbers of leaders and followers, which are the firms that went public in the first and the second half of a hot market respectively. Panel A reports IniR, which is the initial return of an IPO. It is calculated as the percentage change between the offer price and the first trading day closing price. Panel B reports $M t_{0} B_{0}$, which is the market to book ratio at the end of IPO year (i.e. Year 0). It is book debt plus market equity divided by total assets in Year 0. In Panel C, PSec is reported. It is the secondary shares offered as a percentage of total shares offered. In Panel D, TPro is reported. It is the total proceeds as a percentage of total assets in Year 0. VCap, in Panel E, is equal to 1 if an IPO firm is backed by a venture capital firm, and to 0 otherwise. Age, in Panel F, is the difference between the IPO year and the foundation year of a firm. All variables are winsorized at 5\%, except VCap and Age. Age is in natural logarithms. 1 is added to each observation of Age when taking the natural logarithm to prevent the cases of $\ln (0)$. Mean values are reported and $t$ statistics are provided for testing the difference in means. IPO underpricing data of the first hot market is obtained from Prof. Ritter's website, as CRSP covers NASDAQ stocks from Dec. 1972.

\begin{tabular}{|c|c|c|c|c|c|c|c|c|c|c|}
\hline & 1 & 2 & 3 & 4 & 5 & 6 & 7 & 8 & 9 & All \\
\hline Length & 16 & 13 & 12 & 18 & 14 & 13 & 17 & 18 & 14 & 15.00 \\
\hline$N_{L}$ & 251 & 81 & 198 & 266 & 152 & 185 & 345 & 353 & 87 & 1,918 \\
\hline$N_{F}$ & 243 & 159 & 226 & 223 & 175 & 260 & 473 & 284 & 68 & 2,111 \\
\hline \multicolumn{11}{|c|}{ Panel A: IPO Underpricing } \\
\hline Leaders & 18.59 & 20.18 & 18.8 & 9.58 & 12.57 & 15.18 & 20.93 & 42.37 & 13.89 & 21.6 \\
\hline Followers & 6.66 & 13.05 & 4.99 & 9.62 & 13.54 & 11.69 & 15.95 & 37.74 & 11.27 & 14.88 \\
\hline t stat. & - & 1.97 & 7.78 & -0.02 & -0.51 & 2.03 & 3.25 & 1.73 & 0.86 & 6.81 \\
\hline \multicolumn{11}{|c|}{ Panel B: Market to Book Ratios } \\
\hline Leaders & 2.16 & 2.84 & 2.44 & 2.36 & 2.97 & 2.6 & 3.27 & 5.78 & 2.88 & 3.45 \\
\hline Followers & 1.85 & 2.14 & 2.13 & 1.77 & 2.41 & 2.28 & 2.92 & 2.91 & 2.95 & 2.5 \\
\hline t stat. & 0.83 & 1.87 & 1.8 & 4.12 & 2.79 & 1.94 & 2.31 & 12.79 & -0.18 & 11.72 \\
\hline \multicolumn{11}{|c|}{ Panel C: Secondary Shares } \\
\hline Leaders & 21.43 & 13.47 & 18.43 & 14.1 & 14.04 & 10.3 & 11.26 & 3.59 & 11.49 & 12.55 \\
\hline Followers & 21.15 & 14.82 & 17 & 11.23 & 10.13 & 7.68 & 6.58 & 1.39 & 13.71 & 10.45 \\
\hline t stat. & 0.14 & -0.52 & 0.74 & 1.84 & 1.99 & 1.88 & 4.46 & 3.15 & -0.74 & 3.79 \\
\hline \multicolumn{11}{|c|}{ Panel D: Total Proceeds } \\
\hline Leaders & 44.54 & 50.75 & 70.05 & 54.42 & 57.59 & 59.46 & 67.56 & 64.2 & 60.31 & 61.72 \\
\hline Followers & 43.76 & 61.71 & 52.35 & 54.65 & 65.18 & 59.21 & 66.43 & 54.4 & 51.7 & 59.15 \\
\hline t stat. & 0.13 & -2.01 & 5.08 & -0.07 & -2.13 & 0.08 & 0.49 & 3.60 & 1.73 & 2.26 \\
\hline \multicolumn{11}{|c|}{ Panel E: Venture Capital Backing } \\
\hline Leaders & 0.09 & 0.28 & 0.34 & 0.33 & 0.55 & 0.41 & 0.46 & 0.66 & 0.4 & 0.41 \\
\hline Followers & 0.14 & 0.28 & 0.31 & 0.3 & 0.51 & 0.37 & 0.42 & 0.73 & 0.56 & 0.4 \\
\hline t stat. & -1.54 & 0.02 & 0.74 & 0.83 & 0.57 & 0.69 & 1.1 & -1.91 & -1.95 & 0.65 \\
\hline \multicolumn{11}{|c|}{ Panel F: Firm Age } \\
\hline Leaders & 2.6 & 1.77 & 1.99 & 2.04 & 2.46 & 2.27 & 2.03 & 1.78 & 2.55 & 2.12 \\
\hline Followers & 2.47 & 2.06 & 1.97 & 2.03 & 2.25 & 2.22 & 2.06 & 2.01 & 2.22 & 2.13 \\
\hline t stat. & 0.28 & -2.00 & 0.19 & 0.09 & 2.12 & 0.54 & -0.37 & -3.85 & 2.09 & -0.87 \\
\hline
\end{tabular}


Table 2. Descriptive Statistics for IPO Firms

Descriptive statistics for the IPO firms classified as leaders and followers in the 9 hot markets that were at least a year long and that took place between 1970 and 2008. Sales $i$ and Assets $s_{i}$ are net sales and total assets in Year $i$ respectively. $\Delta$ Sales $_{i}$ and $\Delta$ Assets $_{i}$ are percentage growths in net sales and total assets from Year -1 to Year $i$ respectively. Net sales and total assets are in millions of 2008 dollars. Debt $_{i}$ is long-term debt, Prof $f_{i}$ is EBITDA, and $\operatorname{CapX}_{i}$ is capital expenditures in Year $i$ as a percentage of the value of total assets in Year $i . \Delta$ Debt $_{i}, \Delta \operatorname{Prof}_{i}$, and $\Delta C a p X_{i}$ are percentage changes in long-term debt, EBITDA, and capital expenditures from $Y$ ear -1 to $Y$ ear $i$ respectively. All variables are winsorized at $5 \%$, except Sales $_{i}$ and Assets $_{i}$, which are in natural logarithms. Mean values are reported and t statistics are provided for testing the difference in means.

\begin{tabular}{|c|c|c|c|c|c|c|c|c|c|}
\hline Year & -1 & 0 & 1 & 2 & 3 & 0 & 1 & 2 & 3 \\
\hline & \multicolumn{5}{|c|}{ Sales $_{i}$} & \multicolumn{4}{|c|}{$\Delta$ Sales $_{i}$} \\
\hline Leaders & 2.98 & 3.67 & 4.14 & 4.33 & 4.43 & 102.09 & 254.26 & 331.91 & 416.62 \\
\hline Followers & 3 & 3.56 & 3.88 & 4.03 & 4.19 & 91.03 & 197.55 & 297.84 & 411.39 \\
\hline t stat. & -0.21 & 1.5 & 3.44 & 3.75 & 2.82 & 2.13 & 4.14 & 1.64 & 0.18 \\
\hline & \multicolumn{5}{|c|}{ Assets $_{i}$} & \multicolumn{4}{|c|}{$\Delta$ Assets $_{i}$} \\
\hline Leaders & 3.24 & 4.38 & 4.6 & 4.64 & 4.63 & 308.97 & 431.08 & 460.75 & 527.67 \\
\hline Followers & 3.32 & 4.27 & 4.37 & 4.41 & 4.51 & 248.4 & 315.11 & 406.29 & 488.1 \\
\hline t stat. & -1.34 & 2.4 & 4.33 & 3.82 & 1.76 & 4.7 & 6.31 & 2.32 & 1.33 \\
\hline & \multicolumn{5}{|c|}{$\operatorname{Cap} X_{i}$} & \multicolumn{4}{|c|}{$\Delta \operatorname{Cap}_{i}$} \\
\hline Leaders & 9.95 & 8.21 & 9.48 & 7.64 & 6.56 & 240.33 & 560.59 & 522.44 & 488.82 \\
\hline Followers & 9.35 & 8.51 & 9.02 & 7.46 & 6.57 & 232.81 & 452.8 & 498.25 & 553.15 \\
\hline t stat. & 1.86 & -0.97 & 1.47 & 0.6 & -0.05 & 0.6 & 3.62 & 0.55 & -1.52 \\
\hline & \multicolumn{5}{|c|}{ Prof $_{i}$} & \multicolumn{4}{|c|}{$\Delta \operatorname{Prof}_{i}$} \\
\hline Leaders & -1.62 & 2.96 & -0.49 & -0.25 & 2.34 & 79.72 & 140.72 & 151.06 & 138.93 \\
\hline Followers & -1.14 & 2.74 & -1.54 & -1.55 & 0.63 & 70.92 & 93.31 & 123.15 & 138.46 \\
\hline t stat. & -0.37 & 0.26 & 1.05 & 1.25 & 1.68 & 1.3 & 3.29 & 1.54 & 0.02 \\
\hline & \multicolumn{5}{|c|}{ Debt $_{i}$} & \multicolumn{4}{|c|}{$\Delta D_{e b t_{i}}$} \\
\hline Leaders & 0.2 & 0.11 & 0.13 & 0.16 & 0.16 & 38.08 & 220.73 & 405.9 & 637.11 \\
\hline Followers & 0.2 & 0.11 & 0.13 & 0.15 & 0.15 & 24.42 & 193.39 & 417.66 & 632.33 \\
\hline t stat. & 0.52 & -0.17 & 0.34 & 1.18 & 0.84 & 1.73 & 1.11 & -0.26 & 0.07 \\
\hline
\end{tabular}


Table 3. Underpricing and Growth Opportunities of Leaders

The results of the OLS models (1)-(6):

$Y=\beta_{0}+\beta_{1} L+\beta_{2}$ Size $_{-1}+\beta_{3}$ Debt $_{-1}+\beta_{4}$ Prof $_{-1}+\beta_{5}$ CapX $_{-1}+\beta_{6}$ VCap $+\beta_{7}$ PSec $+\beta_{8}$ TPro $+\beta_{9} d I n d+\epsilon$

IniR is the initial return of an IPO. It is calculated as the percentage change between the offer price and the first trading day closing price. $M t o B_{0}$ is the market to book ratio at the end of IPO year. It is book debt plus market equity divided by total assets. $L$ is a binary variable that takes the value of $1(0)$ if the firm is a leader (follower) in a hot market. Size -1 is the firm size in Year - 1. Natural logarithms of net sales, total assets, and age are used as Size $_{-1}$ proxies. Net sales and total assets are measured in millions of 2008 dollars. Age is the difference between the IPO year and foundation year plus one year (to prevent $\ln (0))$. Debt $t_{-1}$ is long-term debt, Prof $f_{-1}$ is EBITDA, and $C_{a p} X_{-1}$ is capital expenditures in Year -1 . These three variables are scaled by total assets of $Y$ ear -1 and are in percentage terms. VCap is equal to 1 if an IPO firm is backed by a venture capital firm, and to 0 otherwise. PSec is the secondary shares offered as a percentage of total shares offered. TPro is the total proceeds as a percentage of total assets in Year 0. dInd is a matrix of dummies for 3-digit SIC industry codes. The coefficients of $d I n d$ are not reported. $\beta_{0}$ is the constant term, and $\epsilon$ is the error term. Robust t-statistics are in parentheses. ***, **, and $*$ stand for significance at 1,5 , and 10 percent levels respectively.

\begin{tabular}{|c|c|c|c|c|c|c|}
\hline & (1) & $(2)$ & (3) & (4) & $(5)$ & (6) \\
\hline $\mathrm{Y}$ & $\operatorname{IniR}$ & IniR & IniR & $M t o B_{0}$ & $M t o B_{0}$ & $M t_{o} B_{0}$ \\
\hline$L$ & $\begin{array}{r}4.49^{* * *} \\
(4.79)\end{array}$ & $\begin{array}{r}4.21^{* * *} \\
(4.56)\end{array}$ & $\begin{array}{r}4.30^{* * *} \\
(4.58)\end{array}$ & $\begin{array}{c}0.72^{* * *} \\
(11.05)\end{array}$ & $\begin{array}{c}0.67^{* * *} \\
(10.55)\end{array}$ & $\begin{array}{r}0.73^{* * *} \\
(10.77)\end{array}$ \\
\hline Sales $_{-1}$ & $\begin{array}{c}-0.66^{* *} \\
(-2.03)\end{array}$ & & & $\begin{array}{r}-0.13^{* * *} \\
(-5.71)\end{array}$ & & \\
\hline Assets $_{-1}$ & & $\begin{array}{r}-1.99^{* * *} \\
(-4.28)\end{array}$ & & & $\begin{array}{r}-0.37^{* * * *} \\
(-11.38)\end{array}$ & \\
\hline Age & & & $\begin{array}{r}-1.84^{* * *} \\
(-3.43)\end{array}$ & & & $\begin{array}{r}-0.16^{* * *} \\
(-4.07)\end{array}$ \\
\hline Debt-1 & $\begin{array}{r}-14.23^{* * *} \\
(-6.01)\end{array}$ & $\begin{array}{r}-12.66^{* * *} \\
(-5.21)\end{array}$ & $\begin{array}{r}-13.81^{* * *} \\
(-5.78)\end{array}$ & $\begin{array}{r}-0.74^{* * *} \\
(-4.29)\end{array}$ & $\begin{array}{r}-0.44^{* *} \\
(-2.56)\end{array}$ & $\begin{array}{r}-0.79 * * * \\
(-4.52)\end{array}$ \\
\hline $\operatorname{Prof}_{-1}$ & $\begin{array}{r}-0.09 * * * \\
(-3.92)\end{array}$ & $\begin{array}{r}-0.09^{* * *} \\
(-4.33)\end{array}$ & $\begin{array}{r}-0.11^{* * *} \\
(-5.69)\end{array}$ & $\begin{array}{r}-0.00 * * \\
(-2.50)\end{array}$ & $\begin{array}{r}-0.00^{* * *} \\
(-2.60)\end{array}$ & $\begin{array}{r}-0.01^{* * *} \\
(-5.77)\end{array}$ \\
\hline $\operatorname{Cap}_{-1}$ & $\begin{array}{r}0.17^{* * *} \\
(2.88)\end{array}$ & $\begin{array}{r}0.16^{* * *} \\
(2.62)\end{array}$ & $\begin{array}{r}0.17^{* * *} \\
(2.73)\end{array}$ & $\begin{array}{r}0.02^{* * *} \\
(3.80)\end{array}$ & $\begin{array}{r}0.01^{* * *} \\
(3.01)\end{array}$ & $\begin{array}{r}0.02^{* * *} \\
(3.68)\end{array}$ \\
\hline$V C a p$ & $\begin{array}{c}1.90^{*} \\
(1.78)\end{array}$ & $\begin{array}{r}2.50^{* *} \\
(2.34)\end{array}$ & $\begin{array}{c}1.78^{*} \\
(1.67)\end{array}$ & $\begin{array}{r}0.12 \\
(1.58)\end{array}$ & $\begin{array}{r}0.22^{* * *} \\
(3.01)\end{array}$ & $\begin{array}{r}0.07 \\
(0.88)\end{array}$ \\
\hline PSec & $\begin{array}{r}-0.15^{* * *} \\
(-5.35)\end{array}$ & $\begin{array}{r}-0.15^{* * *} \\
(-5.22)\end{array}$ & $\begin{array}{r}-0.13^{* * *} \\
(-4.64)\end{array}$ & $\begin{array}{r}-0.00 \\
(-0.38)\end{array}$ & $\begin{array}{r}0.00 \\
(0.10)\end{array}$ & $\begin{array}{r}-0.00 \\
(-0.14)\end{array}$ \\
\hline TPro & $\begin{array}{r}0.11^{* * *} \\
(9.11)\end{array}$ & $\begin{array}{r}0.14^{* * *} \\
(9.61)\end{array}$ & $\begin{array}{r}0.11^{* * *} \\
(9.75)\end{array}$ & $\begin{array}{r}0.01^{* * *} \\
(6.74)\end{array}$ & $\begin{array}{r}0.01^{* * *} \\
(10.78)\end{array}$ & $\begin{array}{r}0.00^{* * * *} \\
(5.34)\end{array}$ \\
\hline Con. & $\begin{array}{r}16.14^{* * *} \\
(11.45)\end{array}$ & $\begin{array}{r}19.09^{* * *} \\
(12.73)\end{array}$ & $\begin{array}{r}18.12^{* * *} \\
(10.73)\end{array}$ & $\begin{array}{c}2.54^{* * *} \\
(27.08)\end{array}$ & $\begin{array}{c}3.08^{* * *} \\
(29.56)\end{array}$ & $\begin{array}{c}2.61^{* * *} \\
(21.70)\end{array}$ \\
\hline Obs. & 2,711 & 2,711 & 2,677 & 2,766 & 2,766 & 2,674 \\
\hline R-sq. & 0.12 & 0.12 & 0.12 & 0.12 & 0.16 & 0.11 \\
\hline
\end{tabular}


Table 4. Ex-ante Characteristics and Ex-post Performance of Leaders The results of the logistic model (1):

$$
L=b_{0}+b_{1} \text { Size }_{-1}+b_{2} \text { Debt }_{-1}+b_{3} \text { Prof }_{-1}+b_{4} \text { CapX }_{-1}+b_{5} \text { VCap }+b_{6} \text { PSec }+b_{7} \text { TPro }+b_{8} d I n d+e
$$

and the OLS models (2)-(5):

$Y=\beta_{0}+\beta_{1} L+\beta_{2}$ Size $_{-1}+\beta_{3}$ Debt $_{-1}+\beta_{4}$ Prof $_{-1}+\beta_{5}$ CapX $_{-1}+\beta_{6}$ VCap $+\beta_{7}$ PSec $+\beta_{8}$ TPro $+\beta_{9} d I n d+\epsilon$

$L$ is a binary variable that takes the value of $1(0)$ for the IPOs that took place in the first (second) half of a hot market. $\Delta$ Sales $_{1}$ and $\Delta$ Assets $_{1}$ are percentage growths from Year -1 to Year 1 in net sales and total assets, which are measured in millions of 2008 dollars, respectively. $\Delta \operatorname{Prof}_{1}$, and $\Delta \operatorname{Cap}_{1}$ are percentage changes from Year -1 to Year 1 in EBITDA, and capital expenditures respectively. Sales -1 and Assets $_{-1}$ are the natural logarithms of net sales and total assets in $Y$ ear -1 , measured in millions of 2008 dollars. Prof $f_{-1}$ is EBITDA, and $C_{a p} X_{-1}$ is capital expenditures in Year -1 . These two variables are scaled by total assets of $Y e a r-1$ and are in percentage terms. VCap is equal to 1 if an IPO firm is backed by a venture capital firm, and to 0 otherwise. PSec is the secondary shares offered as a percentage of total shares offered. TPro is the total proceeds as a percentage of total assets in Year 0. dInd is a matrix of dummies for 3-digit SIC industry codes. The coefficients of $d I n d$ are not reported. $b_{0}$ and $\beta_{0}$ are the constant terms. $e$ and $\epsilon$ are the error terms. Robust t-statistics are in parentheses. ${ }^{* * *},{ }^{* *}$, and ${ }^{*}$ stand for significance at 1,5 , and 10 percent levels respectively.

\begin{tabular}{|c|c|c|c|c|c|}
\hline & (1) & (2) & (3) & (4) & $(5)$ \\
\hline $\mathrm{Y}$ & $L$ & $\Delta$ Sales $_{1}$ & $\Delta$ Assets $_{1}$ & $\Delta \operatorname{Cap}_{1}$ & $\Delta \operatorname{Prof}_{1}$ \\
\hline$L$ & & $\begin{array}{r}49.85^{* * *} \\
(4.05)\end{array}$ & $\begin{array}{r}109.85^{* * * *} \\
(6.96)\end{array}$ & $\begin{array}{r}125.50^{* * *} \\
(4.46)\end{array}$ & $\begin{array}{r}39.43^{* *} \\
(2.57)\end{array}$ \\
\hline Assets $_{-1}$ & $\begin{array}{r}-0.04 \\
(-1.13)\end{array}$ & $\begin{array}{r}-38.80^{* * *} \\
(-7.51)\end{array}$ & $\begin{array}{r}-132.98^{* * *} \\
(-19.58)\end{array}$ & $\begin{array}{r}-203.50^{* * *} \\
(-16.04)\end{array}$ & $\begin{array}{r}-27.01^{* * * *} \\
(-3.77)\end{array}$ \\
\hline Debt-1 & $\begin{array}{r}0.24 \\
(1.12)\end{array}$ & $\begin{array}{r}-107.60^{* * *} \\
(-3.34)\end{array}$ & $\begin{array}{r}-109.26^{* *} \\
(-2.45)\end{array}$ & $\begin{array}{r}-9.51 \\
(-0.12)\end{array}$ & $\begin{array}{l}-60.78 \\
(-1.55)\end{array}$ \\
\hline $\operatorname{Prof}_{-1}$ & $\begin{array}{r}-0.00 \\
(-1.21)\end{array}$ & $\begin{array}{r}-5.20^{* * * *} \\
(-17.72)\end{array}$ & $\begin{array}{r}-3.52^{* * *} \\
(-9.43)\end{array}$ & $\begin{array}{r}-2.21^{* * *} \\
(-3.78)\end{array}$ & $\begin{array}{r}-1.34^{* * *} \\
(-4.80)\end{array}$ \\
\hline $\operatorname{Cap} X_{-1}$ & $\begin{array}{c}0.01^{*} \\
(1.65)\end{array}$ & $\begin{array}{r}4.86^{* * *} \\
(5.41)\end{array}$ & $\begin{array}{r}3.58^{* * * *} \\
(3.21)\end{array}$ & $\begin{array}{r}-30.31^{* * *} \\
(-15.98)\end{array}$ & $\begin{array}{r}1.38 \\
(1.32)\end{array}$ \\
\hline VCap & $\begin{array}{r}-0.05 \\
(-0.49)\end{array}$ & $\begin{array}{r}38.64^{* * *} \\
(2.81)\end{array}$ & $\begin{array}{r}10.98 \\
(0.59)\end{array}$ & $\begin{array}{l}21.65 \\
(0.67)\end{array}$ & $\begin{array}{r}42.52^{* *} \\
(2.31)\end{array}$ \\
\hline PSec & $\begin{array}{r}0.01^{* * * *} \\
(3.23)\end{array}$ & $\begin{array}{l}-0.56^{*} \\
(-1.94)\end{array}$ & $\begin{array}{r}-1.33^{* * *} \\
(-2.96)\end{array}$ & $\begin{array}{r}-1.85^{* *} \\
(-2.26)\end{array}$ & $\begin{array}{r}0.15 \\
(0.32)\end{array}$ \\
\hline TPro & $\begin{array}{r}0.00 \\
(0.73)\end{array}$ & $\begin{array}{r}-2.16^{* * *} \\
(-7.56)\end{array}$ & $\begin{array}{r}-2.58^{* * *} \\
(-7.05)\end{array}$ & $\begin{array}{r}-2.90^{* * *} \\
(-4.74)\end{array}$ & $\begin{array}{r}-1.20^{* * *} \\
(-3.58)\end{array}$ \\
\hline Con. & & $\begin{array}{r}431.84^{* * *} \\
(12.77)\end{array}$ & $\begin{array}{r}902.54^{* * * *} \\
(20.37)\end{array}$ & $\begin{array}{r}1,599.70^{* * *} \\
(20.01)\end{array}$ & $\begin{array}{r}235.99^{* * * *} \\
(5.41)\end{array}$ \\
\hline $\begin{array}{l}\text { Obs. } \\
\text { R-sq. }\end{array}$ & 2648 & $\begin{array}{r}2528 \\
0.30\end{array}$ & $\begin{array}{r}2621 \\
0.29\end{array}$ & $\begin{array}{r}2574 \\
0.22\end{array}$ & $\begin{array}{r}2608 \\
0.03\end{array}$ \\
\hline
\end{tabular}




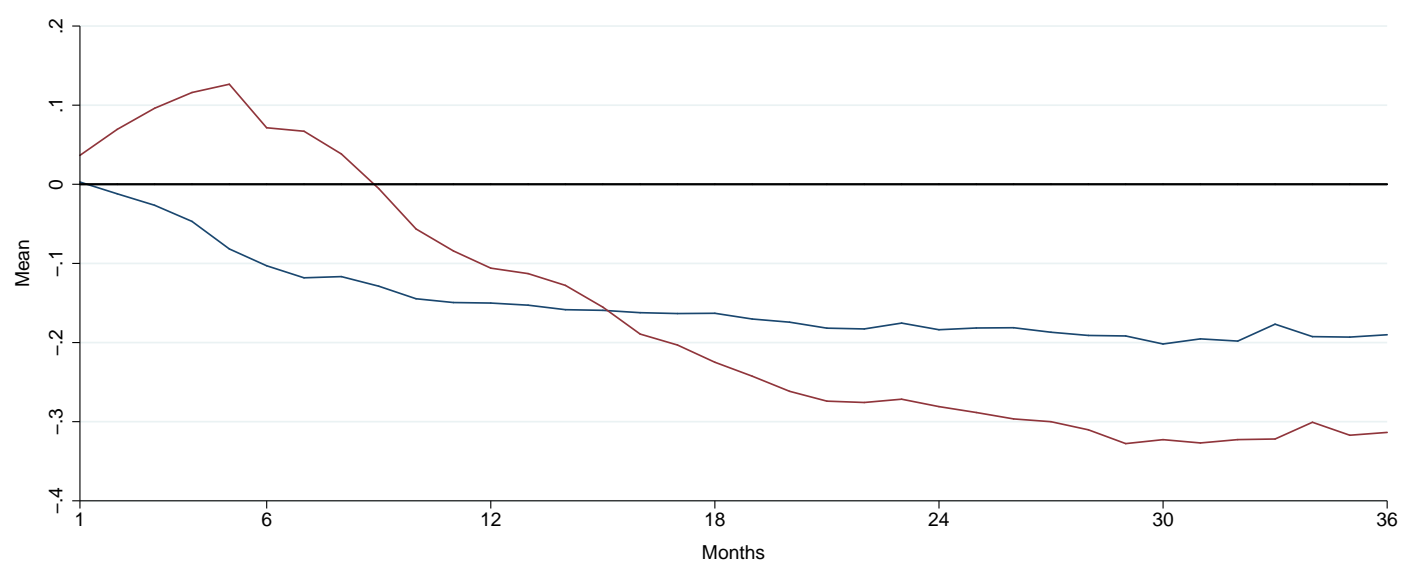

(a)

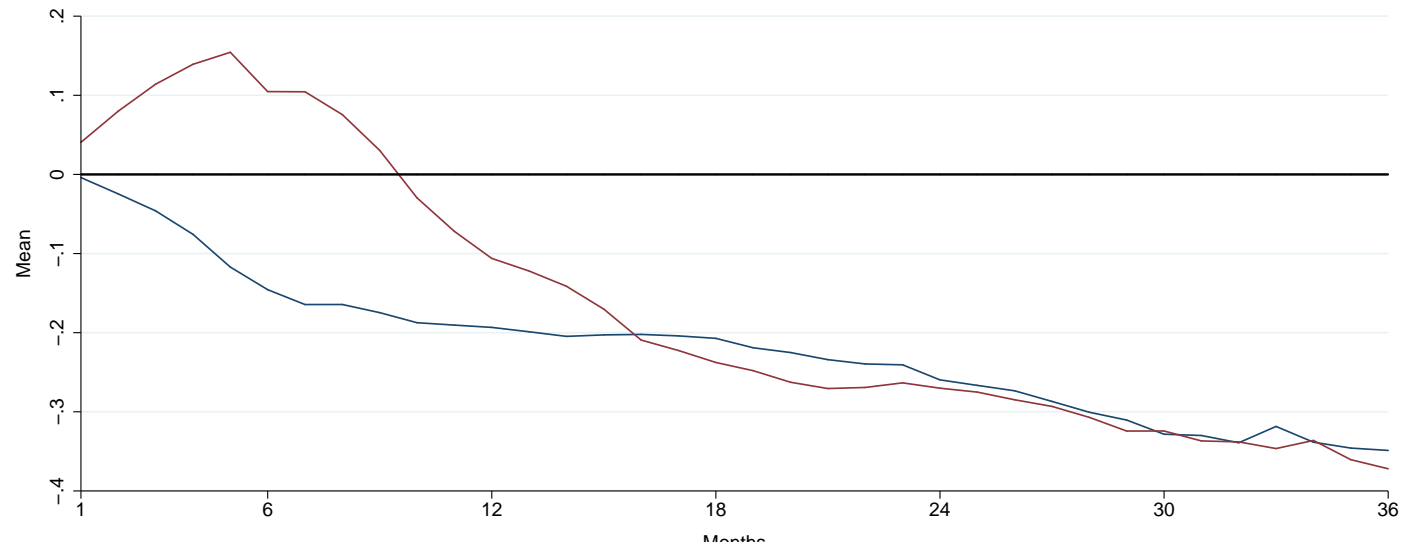

(b)

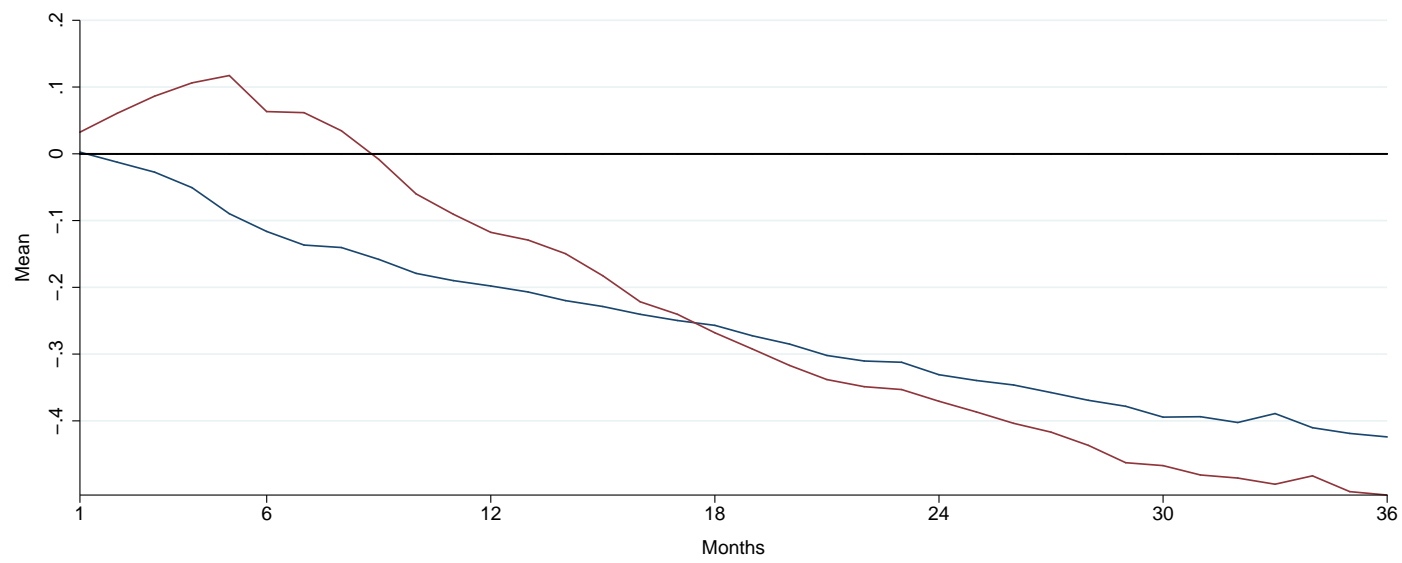

(c)

Figure 5. Long-run performance of leaders and followers. The mean buy and hold abnormal returns of leaders and followers in a hot market up to 36 months after their IPOs. The red (blue) lines represent the performance of leaders (followers). In Plot 5a (5b), the benchmark is equally (value) weighted NYSE, AMEX, and NASDAQ stocks. In Plot 5c, it is size portfolios. Quintile breakpoints are determined using NYSE, AMEX, and NASDAQ stocks, and each IPO is allocated to one of the five size portfolios. Breakpoints are updated monthly. 


\section{References}

Alti, Aydogan, 2006, How persistent is the impact of market timing on capital structure?, Journal of Finance 61, 1681 - 1710.

Bayless, Mark, and Susan Chaplinsky, 1996, Is there a window of opportunity for seasoned equity issuance?, The Journal of Finance 51, 253-278.

Benninga, Simon, Mark Helmantel, and Oded Sarig, 2005, The timing of initial public offerings, Journal of Financial Economics 75, 115 - 132.

Benveniste, Lawrence M., Walid Y. Busaba, and William J. Wilhelm, 2002, Information externalities and the role of underwriters in primary equity markets, Journal of Financial Intermediation $11,61-86$.

Benveniste, Lawrence M., Alexander Ljungqvist, Jr. Wilhelm, William J., and Xiaoyun Yu, 2003, Evidence of information spillovers in the production of investment banking services, The Journal of Finance 58, 577-608.

Helwege, Jean, and Nellie Liang, 2004, Initial public offerings in hot and cold markets, The Journal of Financial and Quantitative Analysis 39, 541-569.

Hoffmann-Burchardi, Ulrike, 2001, Clustering of initial public offerings, information revelation and underpricing, European Economic Review 45, 353 - 383.

Ljungqvist, Alexander, and William J. Wilhelm, 2003, IPO pricing in the dot-com bubble., Journal of Finance 58, p723- 752 .

Loughran, Tim, and Jay R. Ritter, 2002, Why don't issuers get upset about leaving money on the table in IPOs?, The Review of Financial Studies 15, 413-443. 
— , 2004, Why has IPO underpricing changed over time?, Financial Management 33, $5-37$.

Lowry, Michelle, 2003, Why does IPO volume fluctuate so much?, Journal of Financial Economics 67, $3-40$.

, and G. William Schwert, 2002, IPO market cycles: Bubbles or sequential learning?, The Journal of Finance 57, 1171-1200.

Pagano, Marco, Fabio Panetta, and Luigi Zingales, 1998, Why do companies go public? an empirical analysis, The Journal of Finance 53, 27-64.

Pastor, Lubos, and Pietro Veronesi, 2005, Rational IPO waves, The Journal of Finance 60, $1713-1757$.

Ritter, Jay R., 1991, The long-run performance of initial public offerings, The Journal of Finance 46, 3-27.

Schultz, Paul, 2003, Pseudo market timing and the long-run underperformance of IPOs, The Journal of Finance 58, 483-517.

Yung, Chris, Gonul Colak, and Wei Wang, 2008, Cycles in the IPO market, Journal of Financial Economics 89, 192 - 208.

Zingales, Luigi, 1995, Insider ownership and the decision to go public, The Review of Economic Studies 62, 425-448. 